NBER WORKING PAPER SERIES

\title{
THE IMPACT OF IMMIGRATION ON NATIVE POVERTY THROUGH LABOR MARKET COMPETITION
}

\author{
Giovanni Peri \\ Working Paper 17570 \\ http://www.nber.org/papers/w17570 \\ NATIONAL BUREAU OF ECONOMIC RESEARCH
1050 Massachusetts Avenue
Cambridge, MA 02138 \\ November 2011
}

This paper was written for the volume "Immigration, Poverty, and Socioeconomic Inequality,". The project was funded by the National Poverty Center at the University of Michigan's Gerald R. Ford School of Public Policy. I thank Steve Raphael and David Card for useful comments and suggestions. Paul Gaggl provided excellent research assistance. The views expressed herein are those of the author and do not necessarily reflect the views of the National Bureau of Economic Research.

NBER working papers are circulated for discussion and comment purposes. They have not been peerreviewed or been subject to the review by the NBER Board of Directors that accompanies official NBER publications.

(C) 2011 by Giovanni Peri. All rights reserved. Short sections of text, not to exceed two paragraphs, may be quoted without explicit permission provided that full credit, including $\odot$ notice, is given to the source. 
The Impact of Immigration on Native Poverty through Labor Market Competition

Giovanni Peri

NBER Working Paper No. 17570

November 2011

JEL No. J3,J61

\begin{abstract}
In this paper I first analyze the wage effects of immigrants on native workers in the US economy and its top immigrant-receiving states and metropolitan areas. Then I quantify the consequences of these wage effects on the poverty rates of native families. The goal is to establish whether the labor market effects of immigrants have significantly affected the percentage of "poor" families among U.S.-born individuals. I consider the decade 2000-2009 during which poverty rates increased significantly in the U.S. As a reference, I also analyze the decade 1990-2000. To calculate the wage impact of immigrants I adopt a simple general equilibrium model of productive interactions, regulated by the elasticity of substitution across schooling groups, age groups and between US and foreign-born workers. Considering the inflow of immigrants by age, schooling and location I evaluate their impact in local markets (cities and states) assuming no mobility of natives and on the US market as a whole allowing for native internal mobility. Our findings show that for all plausible parameter values there is essentially no effect of immigration on native poverty at the national level. At the local level, only considering the most extreme estimates and only in some localities, we find non-trivial effects of immigration on poverty. In general, however, even the local effects of immigration bear very little correlation with the observed changes in poverty rates and they explain a negligible fraction of them.
\end{abstract}

\author{
Giovanni Peri \\ Department of Economics \\ University of California, Davis \\ One Shields Avenue \\ Davis, CA 95616 \\ and NBER \\ gperi@ucdavis.edu
}




\section{Introduction}

In this paper I analyze the effect of immigration on the proportion of American families falling below the poverty line, through the labor market effect that new immigrants may have on native workers. Immigrants are a heterogeneous group of workers with different levels of schooling and age. Some of them compete with specific groups of native workers and complement other groups. Others compete and complement different groups of native workers. Immigrants may also increase or dilute the average level of human capital in the US economy. Each of these effects has an impact on native wages that differs depending on their schooling, their age and their location. The first step of this paper is to analyze the impact of immigrants on wages of natives of different demographic characteristics. The second step is to map these wage effects into effects on the proportion of families falling below the poverty line. Poverty is defined in the conventional way, by considering before tax (transfers) total family income, relative to the federal poverty line, (which is adjusted for inflation and for family size in each year). The mapping of the wage income effects onto changes in poverty rates, therefore, depends on the magnitude of the wage effects, on the importance of wages in total income and on the income distribution of families around the poverty line.

The effect of immigrants on wages of native workers is the source of some debate among economists and is difficult to measure in a credible way. First, the flow of international immigrants in a country or in a local economy depends itself on the wage paid there. Consequently, a positive correlation between immigrants and wages, driven by employment growth in highly productive areas may attenuate any estimate of a causal effect from immigrants to wages. In regression approaches this issue is addressed using instrumental variable techniques ${ }^{1}$. Second, the supply of workers of a skill type affects the productivity and wages of workers of the same (competition) and of different (complementarity) skill types. Hence, a reduced form estimation that does not account for these cross-skill interactions misses most of the effects of immigrants ${ }^{2}$. Third, especially at the local level, immigration may trigger other responses, particularly internal migration of natives, that may themselves attenuate its wage impact. By considering each area as an isolated unit of analysis we may underestimate the effects of immigrants on local labor markets ${ }^{3}$. In spite of these difficulties a

\footnotetext{
${ }^{1}$ E.g. Altonji and Card (1991).

${ }^{2}$ The differece between the "partial effect" and the "overall effect" of immigration on wages of natives in different skill groups is pointed out and discussed in Ottaviano and Peri (forthcoming).

${ }^{3}$ This criticism to the "area approach" was raised in several studies beginning with Borjas, Freeman and Katz
} 
large body of empirical literature has tackled this issue. Each of these problems, however, contributes to make a reduced-form estimation approach of the wage effect of immigration problematic. While solutions exist and have been adopted in the literature, I take a different approach in the present study.

Rather than estimating the wage impact of immigrants in a reduced form regression I simulate this effect, using a labor market equilibrium model. In particular, I adopt the aggregate production/general equilibrium framework, that is emerging as dominant in the national wage studies of immigration (e.g. Borjas (2003), Manacorda et al. (forthcoming) and Ottaviano and Peri (forthcoming)). This framework captures the relevant productive interactions between workers of different demographic characteristics (schooling, experience and national origins) accounting for cross-skill effects on productivity while keeping the number of parameters needed for the simulation tractable. Besides the cross-skill complementarity effects I add a new feature to the model. In the production model, I also consider the potential existence of human capital externalities. Recent empirical studies relative to US cities (Moretti 2004a, 2004b) and US states (Iranzo and Peri 2009) have shown the existence of significant positive productivity effects from the concentration of college graduates. As immigration may increase or decrease the share of college graduates in a locality, depending on its skill intensity, I include this channel in the model allowing for different strength of such externalities ${ }^{4}$.

I use such a model to simulate the wage effects of immigration flows in the period 2000-2009 (and, as a reference, also during the previous decade 1990-2000). The same model is used, at different levels of aggregation, to represent the US economy as a whole, US states and US metropolitan areas. Usually the approach is applied to evaluate what effect immigration has on native wages of different workers nationally. However one can use it to simulate the maximum wage effect of immigrants, in absence of any offsetting migration of natives, for cities and states. While the use of this model for US cities or states is unrealistic because it ignores natives' mobility response to immigrant inflows and the possibility of local specialization in tradable goods, the exercise provides a useful upper bound for the local wage effects of immigration. The calculated national effects, on (1997).

${ }^{4}$ Previous models that analyze the wage effect of immigrants usually do not consider the externality channel. However, we show that, especially following the increased college-intensity of immigration during the 2000-2009 period, this channel may be important when evaluating wage and productivity effects of immigrants. 
the other hand, are the relevant ones in the more realistic scenario of long-run mobility of workers in the U.S.

The model provides a range of simulated wage effects of immigration for native workers of different demographic characteristics. Then I use them to evaluate the impact on poverty. Specifically, I keep the distribution of observable and unobservable characteristics of natives as in 2009 and consider the simulated wage effects of immigration. I then compute the proportion of families in each group whose total income was below the poverty line in actuality and in the counter-factual case, without net immigration in the 2000-2009 period. The difference between the two proportions is the increase in poverty rates caused by immigration. As such effects depend on the density of the income distribution around the poverty line as well as on the wage effect of immigrants, and both of those vary with demographics, I will perform this analysis for different groups (mainly different education, age and gender cells) and I also evaluate the aggregate effects for black and Hispanic individuals. In the simulations I use three different combinations of the relevant parameters: one that I call "most favorable", one that I call "preferred" and one that I call "most pessimistic". They span the range of the reasonable parameters estimates in the literature and are arranged according to the produced wage-impact on natives.

Three results originate from this exercise that are worth emphasizing. First, at the national level the impact of immigration on native poverty rates via wages effects is essentially negligible for any of the chosen parameter configurations, both in the decade 1990-2000 and 2000-2009. The effects consist of extremely small reductions of poverty rates for all groups and decades, except for the group of individuals with a high school degree or less during the decade 1990-2000. During that period natives with no high school diploma experienced an increase in the poverty rate due to immigrants between 0.3 and $0.2 \%$, when I use the "most pessimistic" parameter configuration. For the other configurations of parameters in the period 2000-2009 and for all configurations of parameters, during the period 2000-2009, I find immigration to have a poverty-reduction effect between 0 and $0.51 \%$.

It is worth emphasizing that our data already include the most recent 2009 American Community Survey and therefore are the most up-to-date in measuring recent immigration flows. These data show high-skill intensive immigration during the 2000s. This is because, as I will document below, immigration rates during the 2000s have been small among less educated individuals, dropping significantly from the rates of 1990s, while they have remained high among highly educated 
ones. The large drop in immigration rates of less educated immigrants, mostly due to a drop of immigrants from Mexico, is an interesting and still little known feature of immigration during the decade 2000-2009.

Second, even at the state level, considering local inflows of immigrants and no mobility of natives, the model generally predicts insignificant effects of immigration on poverty. Interestingly, for the period 2000-2009, the only sizeable effects predicted by the model, in states such as Arizona, California, Florida and New Jersey are poverty reductions for groups of workers with no diploma and with high school degree only. For the period 1990-2000, on the other hand, the model predicts some increases in native poverty rates driven by competition from immigrants. Only simulations for Arizona, Colorado and Nevada, however, show increases as large as $0.7-1.0 \%$ in the poverty rates of the least educated group when using the "most pessimistic" parameter configuration. Using the "preferred" parameter configuration our simulations never find changes in poverty rates larger than $0.4 \%$ even in those states. In the overwhelming majority of the top ten states our model shows simulated effects of immigration smaller than $0.1 \%$ on native poverty rates of any group. Notice that, both in the period 1990-2000 and in the period 2000-2009, the correlation between the native poverty changes and the simulated effects of immigration was essentially zero. In short, immigration drove a negligible fraction of poverty changes at the state level and often the simulated effects have a negligible correlation with the actual changes in poverty rates.

Finally, the analysis at the MSA level reveals that immigration had hardly anything to do with the evolution of native poverty even at the local level. Considering the 20 MSAs with the largest immigration rates, we learn that during the decade 2000-2009 most of them experienced higher immigration rates among college educated than among high school graduates. Hence, our model predicts mostly positive wage effects for the least educated natives. This produced a povertyreduction effect of immigrants in most cases. In the period 1990-2000, on the other hand, some cities did receive large inflows of less educated immigrants and relatively small inflows of highly educated ones. The most extreme cases were Las Vegas (NV), Reno (NV), Austin (TX), McAllen (TX) and Huston (TX). Still, even in those cases, and considering the full local effect of immigrants with no attenuation through native migration, I obtain increases in poverty rates for the least educated natives close to $2 \%$ (Reno and Austin) or 1.5\% (Las Vegas and McAllen) only when using the "most pessimistic" parameter configuration. For all other cities I obtain effects smaller that $0.5 \%$ and using the preferred or the most favorable configuration of parameters I never obtain any effect 
larger than $1 \%$ even for those extreme cases. Moreover, for those cities with the largest simulated effects of immigration the actual poverty rates decreased in the 1990s (by 10\% in Austin, by $8 \%$ in McAllen and by $3 \%$ in Reno) confirming no correlation between the potential effect of immigrants and actual change in poverty rates.

Overall the imputed effect of immigration on poverty at the national and local level in the 2000s are smaller by one order of magnitude than the actual poverty changes. Moreover usually the model predicts that immigration reduced poverty of less educated natives while the actual rates increased. Finally when analyzing the potential immigration-induced effects across cities and states as closed economies I find no correlation or even negative correlation with actual poverty changes. This is a sign that the immigration was not very relevant in affecting native poverty either at the national, state or local level.

The rest of the paper is organized as follows. In section 2 I briefly describe the model used to evaluate the equilibrium wage effects of immigration and I describe its parameterization, using micro-estimates from the literature. In section 3 I describe the trends of immigration during the 1990s and the 2000s for the U.S. as a whole and for the ten major immigration-receiving states and for the top twenty immigration-receiving Metropolitan Statistical Areas (MSAs). I also describe the trends of the poverty rates among demographic groups in the U.S. and in the considered states and MSAs. In section $4 \mathrm{I}$ simulate the effects of immigration on native wages across different demographic groups and I calculate the implied effects on poverty rates for different demographic groups. In the same section I evaluate to what extent immigration can explain the evolution of actual poverty rates. Section 5 does the same analysis considering top immigration states and MSAs. Section 6 concludes the paper.

\section{Model}

The framework that I use is one in which firms demand labor of different skill groups and equate the wages to the marginal productivity of each worker. Workers are heterogeneous according to their schooling and age and each group competes in a separate labor market. Different workers are combined in production in a labor composite. On top of labor, firms use physical capital to produce homogeneous and perfectly tradable output. Workers supply a fixed amount of labor each, so that their number (and in turn the population in working age for each skill group) determines their 
supply. Physical capital adjusts to keep its return equal to the rate of inter-temporal preferences net of the discount rate. Immigration is a supply shock that affects different skill groups differently.

Slightly adjusting the model used in Ottaviano and Peri (forthcoming) and in line with Docquier et al. (2010), the production function of the representative economy (be it the US, or one state or metropolitan area) in year $t$ is as follows:

$$
Y_{t}=\widetilde{A}_{t} K_{t}^{\alpha} Q_{t}^{1-\alpha}
$$

Where $Y_{t}$ is output, chosen as the numeraire, $\widetilde{A}_{t}$ is total factor productivity $K_{t}$ is physical capital, $Q_{t}$ is a labor composite described below and is the elasticity of output to capital. Assuming that physical capital is mobile across nations (or cities and states) the returns to physical capital are equalized across countries. If $R^{*}$ denotes the international net rate of return to capital, the following arbitrage condition implicitly defines the equilibrium capital-to-labor ratio in the economy:

$$
R^{*}=(1-\alpha) \widetilde{A}_{t} K_{t}^{-\alpha} Q_{t}^{\alpha}
$$

In a small open economy the above condition holds in the short and in the long run. In a closed economy as in Ramsey (1926) (or Solow 1951) condition (2) holds in the long-run (balanced growth path), with $R^{*}$ being a function of the inter-temporal discount rate of individuals (or of the savings rate $)^{5}$. Hence, in the long-run we can substitute this arbitrage condition into (1) to obtain an expression of aggregate output as linear function of the aggregate labor $Q_{t}$ :

$$
Y_{t}=A_{t} Q_{t}
$$

where $A_{t} \equiv \widetilde{A}_{t}^{1 / \alpha}\left[(1-\alpha) / R^{*}\right]^{(1-\alpha) / \alpha}$ is an increasing function of TFP and is referred to as modified TFP henceforth. Notice, as it is clear from expression (1), that with endogenous capital adjustment, output is a linear function of employment. Hence, an inflow of workers has no effect on average wages, which only depend on productivity. Moreover, an inflow of workers that is balanced across skill types will have no effect on any wage. In the long run (ten years) and for economies with free capital circulation (such as US cities or states) endogenous capital response is a very reasonable assumption.

\footnotetext{
${ }^{5}$ As long as immigration does not change the savings rate of an economy the pre- and post- migration $R^{*}$ are identical.
} 
The labor composite is defined as a nested CES aggregate of different types of workers as follows. First I distinguish between highly educated $\left(Q_{H}\right)$ and less educated $\left(Q_{L}\right)$ workers who are combined in the following way:

$$
Q_{t}=\left[\theta_{H} Q_{H, t}^{\frac{\sigma_{H L}-1}{\sigma_{H} L}}+\left(1-\theta_{H}\right) Q_{L, t}^{\frac{\sigma_{H L}-1}{\sigma_{H L}}}\right]^{\frac{\sigma_{H L}}{\sigma H L-1}}
$$

In equation (4), the parameter $\sigma_{H L}$ is the elasticity between highly and less educated and $\theta_{H}$ is the relative productivity of highly educated. In the empirical implementation highly educated are individuals with some college education or more, while less educated are high school graduate or less. In some studies (e.g. Borjas 2003) the group of less educated workers is further split into two sub-groups - high school graduates and those with no diploma-with an elasticity of substitution of $\sigma_{L L}$ between them. In most cases, however, the literature (e.g. Katz and Murphy, 1992, Goldin and Katz, 2008) has used one homogeneous group for less educated workers. In one configuration of the simulated model (the "most pessimistic" scenario) I will consider this further nesting, but I am not including it here to keep the notation simple. Then each group of workers with homogenous schooling $k$ is divided into two experience groups, young $\left(Q_{Y}\right)$ and old $\left(Q_{O}\right)$, also combined in a CES fashion:

$$
Q_{k t}=\left[\theta_{Y} Q_{Y, k t}^{\frac{\sigma_{Y O}-1}{\sigma_{Y O}}}+\left(1-\theta_{Y}\right) Q_{O, k t}^{\frac{\sigma_{Y O}-1}{\sigma_{Y O}}}\right]^{\frac{\sigma_{Y O}}{\sigma_{Y O}-1}}
$$

In equation (5) the parameter $\sigma_{Y O}$ is the elasticity between young and old in the schooling group and $\theta_{Y}$ the relative productivity of young workers. Finally within an education-experience group employment of immigrants $(I)$ and of natives $(N)$ are combined in a CES function.

$$
Q_{k j t}=\left[\theta_{I} I_{k j t}^{\frac{\sigma_{I N}-1}{\sigma_{I N}}}+\left(1-\theta_{I}\right) N_{k j t}^{\frac{\sigma_{I N}-1}{\sigma_{I N}}}\right]^{\frac{\sigma_{I N}}{\sigma_{I N}-1}}
$$

I assume that the marginal productivity of each type of workers equals its wage and that the supply of each type of workers is given by a fixed proportion (proxied by the employment rate) of the population of that group. Thus, we can write the wage of native workers of skill $k, j$ as a function of the total supply of labor aggregates which depend on the total number of immigrants and vary with them. Wages for native workers of skill $k, j$ are given by: 


$$
w_{k j, t}=A_{t} \theta_{k} \theta_{j} \theta_{N}\left(\frac{Q_{t}}{Q_{k, t}}\right)^{\frac{1}{\sigma_{H L}}}\left(\frac{Q_{k, t}}{Q_{k j, t}}\right)^{\frac{1}{\sigma_{Y O}}}\left(\frac{Q_{k j, t}}{N_{k j, t}}\right)^{\frac{1}{\sigma_{I N}}}
$$

As the inflow of immigrants changes the relative supplies $\frac{Q_{k, t}}{Q_{t}}, \frac{Q_{k j, t}}{Q_{k, t}}$ and $\frac{N_{k j, t}}{Q_{k j, t}}$ it will alter the wage of natives in different skill groups. I obtain the wage effect of immigration by calculating the wages - including or excluding the new immigrants (between 1990-2000 or between 2000-2009) and taking their difference as a percentage of the pre-migration wage. ${ }^{6}$ These effects will be specific to the education-age group and will depend on the whole distribution of new immigrants across cells.

Finally, as anticipated in the introduction, we consider that productivity may depend on a human capital externality. Using the formulation in Moretti (2004a, 2004b) we write:

$$
A_{t}=A_{0}\left(\exp \left(h_{t}\right)\right)^{\lambda}
$$

where $A_{0}$ captures the part of TFP independent of the human capital externality, and $\lambda$ is the semi-elasticity of the modified TFP to the share of college-educated in the economy, $h_{t}$, including natives and immigrants. Immigration may alter $h_{t}$ if the immigrant distribution between college educated and non educated is different than the one of natives. Moretti (2004a) and Iranzo and Peri (2009) use the formulation as in (8), emphasizing that the externalities depend on the share of college educated, rather than merely on average years of schooling.

\subsection{Parameterization}

The range of parameters that I use in the simulation is represented by three configurations described in Table 1. Three parameters are most important in determining the overall and the relative wage effects of immigrants. The first is $\sigma_{H L}$, the elasticity of substitution between more and less educated. The second is $\sigma_{I N}$, the elasticity of substitution between natives and immigrants within an education and age group. The third is $\lambda$, the intensity of the human capital externality. For each of these parameters I choose an estimate at the high end of the range estimated in the literature and one at the low end of the range and one that is close to the median. The parameter $\sigma_{Y O}$ affects the relative substitutability between young and old workers and is not the focus of our analysis. Hence I keep it fixed at 10, a value within the existing range of estimates (Welch, 1979, Card and Lemieux, 2001, Ottaviano and Peri, forthcoming)

\footnotetext{
${ }^{6}$ The formulas to obtain the percentage wage effect of immigration, derived from equation (7), are in Appendix A.
} 
The parameter $\sigma_{H L}$ has a long history. It has been estimated in several studies beginning in the 1960s. Ciccone and Peri (2005) review some of the estimates and find most of them in the range between 1.5 (lower bound) and 2 (upper bound). I choose those as extreme values and the average 1.75 as the preferred value. I consider the more common structure with two schooling groups (advocated in Card 2009, Goldin and Katz 2008 and Ottaviano and Peri forthcoming) as the preferable specification. Hence, the potential value of the elasticity of substitution between workers with no diploma and workers with high school diploma, $\sigma_{H L}$, is set at infinity. Only in the "most pessimistic" specification I allow imperfect substitutability between those groups with an elasticity of 10, which is at the lower bound of the estimates in Ottaviano and Peri (forthcoming).

The estimates of the parameter $\sigma_{I N}$ have been the focus of some recent papers. Potentially sensitive to the sample chosen and the method of estimation, the elasticity between immigrants and natives in the US has been estimated at 20 by Ottaviano and Peri (forthcoming) and at infinity by Borjas et al. (2008). Using data on California and a different methodology, Peri (2011) finds smaller values of $\sigma_{I N}$ in the neighborhood of 12. Estimates for the UK, provided by Manacorda et al. (forthcoming) find even smaller values, around 6. I only consider the estimates based on U.S. data for the range of our simulations.

As for schooling externalities I use the existing estimates that measure the elasticity of average wages (or total factor productivity) to the share of college educated workers. The existing studies estimate the parameter $\lambda$ across cities or states in the U.S. Moretti (2004a, 2004b) finds an elasticity around 0.75, which is at the high end of the range found in the literature. Acemoglu and Angrist (2000) find a value close to zero and Iranzo and Peri (2009) use a similar formulation and they estimate a parameter value for $\lambda$ of 0.45 .

While the reader should consider the whole range of simulations I believe that the preferred scenario is the most reasonable and in line with most of the existing parameter estimates. The parameterization of the "pessimistic scenario" assumes imperfect substitutability between workers with no diploma and high school graduates which is not supported by the existing empirical studies (e.g. Ottaviano and Peri, forthcoming, Card 2009, Goldin and Katz 2008). I will comment the results obtained in the preferred scenario in greater detail as they are likely to better represent the consensus estimates in the literature. 


\section{Immigration and Poverty: trends in the 1990s and 2000s}

The focus of this paper is the analysis of immigration and its effect on native poverty in the last decade of available data (2000-2009). As a comparison, I also present the simulations for the period 1990-2000, a decade characterized by remarkable and steady economic growth. The present section describes some trends in immigration and poverty.

\subsection{National Trends}

Table 2 shows the net immigration rates at the national level for sixteen cells differentiated by schooling levels (no diploma, high school diploma, some college and college graduates), age groups (young, with less than 20 years of potential working experience and old, with 20 years or more) and gender (male and female). In this and in all the following tables we define "immigration rate" for a group as the net inflow of foreign-born over the period, relative to the resident population (native + immigrants) in the group at the beginning of the period. Immigration during the 1990s presents the well known pattern of immigration rates: large at the extreme of the skill distribution (especially for college educated and individuals with no diploma) and low at intermediate levels (high school diplomas and some college). Overall, the net immigration rate for the decade was $5.8 \%$ implying an inflow of immigrants equal to $0.58 \%$ of the initial resident population in each year. The immigration rate for the more educated group was $4.3 \%$ and for less educated was $7.1 \%$. Hence, during the expansion years of the nineties, immigration was more concentrated among less educated than among more educated. The opposite, however, is true for the 2000s. Relative to the 1990s, net immigration rates for the least educated dropped dramatically, while for the college educated and college graduates immigration rates remained essentially stable. As a consequence, during the most recent decade, immigration rates were significantly larger among more educated (4.1\%) than among less educated people $(2.4 \%)$, nationally. Two more tendencies became evident in the 2000s, relative to the 1990s. First, the drop in immigration rates among less educated was particularly severe among young workers. Net immigration of young individuals with no diploma became negative in the 2000s. Second, while among less educated immigrants, men still represented larger shares, among more educated, women showed larger immigration rates.

These dynamics are very interesting. As the strongest wage competition derives from immigrants of similar demographic characteristics, the adverse competition effects from immigrants for 
young less educated native women (the group at highest risk of poverty in the nation) should have dropped significantly. Hence, the effect of immigration on native poverty might have become even more benign in the 2000s relative to the nineties. Table 3 shows the percentage of individuals in each of the sixteen demographic groups, below the poverty line, as defined by the federal government, for the years 2000 and 2009. The poverty line is defined in terms of family income and depends on the age of the adults and on the number of children in the household. Table A1 in the Table Appendix shows the value of family income denoting the poverty lines for different types of families in 2000. Those thresholds, adjusted by the change in consumption price index, were also applied in 2009 .

As reported in Table 3, the group with the highest poverty rates is that of young women with no diploma. Among them, 34.5\% were below the poverty line in 2000 and a stunning $42.4 \%$ was in poverty after the recession in 2009. Even old women with no diploma had a poverty rate of more than $33 \%$ in 2009. At the opposite end, old, college educated males have negligible poverty rates (of 2-3\%). These data emphasize the higher vulnerability of women with low levels of schooling, usually in the lowest percentiles of the wage income distribution and likely to live as single mothers with children, and hence, at very high risk of poverty. More interesting for our purposes, however, is the change of poverty rates in the considered decades. If the inflow of immigrants has affected wages differentially across demographic groups, then the cells with high immigration rates should show larger increase in poverty rates.

In actuality, even a cursory look at the data in Table 2 reveals that during the 2000s the weakest groups (less educated, young and women) were those experiencing the largest increases in their poverty rates. They were also the groups receiving fewer immigrants. On the other hand the "stronger" groups of more educated and older individuals did not experience any increases in poverty rates, while they experienced relatively large immigration rates. During the 1990s the poverty rates were reduced particularly among older individuals at intermediate to low levels of education, while young individuals with no diploma had already begun to experience increases in poverty rates. Overall, while native poverty rates remained stable or grew little throughout the 1990s, in the 2000s they increased significantly for several groups. The native adult poverty rate increased from $12 \%$ in 2000 to $16 \%$ in 2009 .

Figure 1 shows a simple scatter-plot of changes in native poverty rates and immigration rates across the eighteen skill groups and across the decades 1990-2000 and 2000-2009. While the figure 
is only meant to describe the data it shows a negative correlation, which implies larger increase in poverty rates in cells with lower immigration rates. If wage competition of immigrants was an important driver of changes in poverty across skill groups we should observe the opposite correlation. Obviously, many other factors affect poverty, and hence wages and incomes of natives - and in turn the wage competition effect of immigrants-, even if important, may be completely masked by other factors in the scatter-plot. Figures A1 and A2 in the Appendix show the poverty-immigration correlation separately for the 1990s and for the 2000s. They show a weakly negative correlation between immigration rates and changes in poverty rates, even within each decade.

\subsection{States and MSAs}

Within the general trends described in the pervious section, individual states and MSAs experienced hugely different immigration rates and they also differed in the distribution of immigrants across skills. At the same time, poverty rates were quite different across U.S. states and cities. In this section I describe some of the notable characteristics of immigration in the top ten immigration states and in the top 20 immigration MSAs. I choose the states with the highest immigration rates for the last 20 years. They are, in decreasing order, Nevada, Arizona, Texas, Florida, California, Georgia, Utah, Colorado, New Jersey and I add New York, which in spite of being only 14th in terms of immigration rates in the period 1990-2009, ranks second regarding the percentage of foreign-born (27\% in 2009). Similarly, I choose 16 of the top 20 MSAs in terms of their immigration rates over the last two decades. They include cities in Nevada, Georgia, Texas, Arizona, California, North Carolina, Connecticut, New Jersey and Florida. I add Los Angeles, Miami, New York and San Francisco which are the largest MSAs with more than $30 \%$ of foreign-born population.

Table 4 shows the immigration rates by decade and for each of the four schooling groups in the ten considered states. Some tendencies are clear. First, the overall net immigration rates dropped dramatically from the 1990s to the 2000s. Nevada experienced a stunning immigration rate of $23 \%$ in the 1990 s which was almost cut in half to $12 \%$ in the 2000 s. Arizona experienced a drop from $14.2 \%$ to $7.8 \%$. Old immigration states (such as California and New York) had even larger declines in immigration rates and in the 2000s they experienced immigration rates of $4.2 \%$ and $2.1 \%$, among the lowest in the group. Even more interesting is the composition of immigrants by skills. The states with largest immigration rates and the new immigration states, especially in the 1990s, had a tendency to attract disproportionately large fractions of immigrants among the least 
educated workers. Nevada and Arizona in the 1990s had immigration rates, among individuals with no diploma, equal to $61.6 \%$ and $38.8 \%$ respectively. However, the immigration rates among college educated for those two states were, respectively, "only" $19 \%$ and 10\%. Similarly, new immigration states (such as Colorado, Georgia and Utah) experienced much larger immigration rates among the least educated than among the most educated. On the other hand, states with older tradition of immigration (such as California, New York and New Jersey) attracted a much more balanced inflow of immigrants during the 1990s, with immigration rates for college graduates as large as (or larger than) for individuals with no diploma. During the 2000s, the very large drop in immigration at low levels of schooling, which was a national phenomenon, produced a substantial balancing of immigration rates across skills. This was true especially for states of more recent immigration (such as Arizona and Nevada), while states of old immigration experienced immigration that was strongly biased in favor of college educated individuals. California and New York, for instance, had essentially no net immigration in the group with no diploma, during the 2000s, while they had a 6-10\% immigration rates for the group of college educated.

The change in poverty rates across the considered states for the four schooling groups and the two decades is shown in Table 5. In the 1990s we observe some states with decreasing poverty rates up to $2 \%$ (e.g. Arizona and Texas), several other maintaining them roughly unchanged and only California and New York increased those rates by more than 1\%. In the 2000s however, as a consequence of the deep recession, poverty rates in all states increased significantly and several of them by more than $2 \%$ (not California and New York, however, whose poverty rates increased by less than 1\%). In terms of education groups, the largest increases in poverty rates are observed for individuals with no diploma in the 2000s. In states like Colorado, Georgia and Utah, the poverty rates of the least educated increased at an alarming rate, adding more than $7 \%$ of the group to the "poor" families. Even among workers with high school diplomas and some college (but not among college graduates) it is not uncommon to observe increase in poverty rates in the order of 2-3\% during the 2000s (e.g. in Arizona, Colorado, Georgia and Florida). These large and unequal changes in poverty rates, however, do not bear any prima-facie correlation with immigration rates by state and education group. The scatter-plot of changes in poverty rates and immigration rates by education groups in the ten states for the periods 1990-2000 and 2000-2009, shown in Figure 2, reveals a very small, negative and not significant correlation between the two.

The immigration rates and changes in poverty rates by schooling group for the 20 MSAs con- 
sidered are shown in Tables 6 and 7 . These tables confirm the patterns shown at the state level. There are some cities in Nevada, Arizona and Texas experiencing massive immigration rates during the 1990s. Reno, McAllen and Las Vegas, for instance, all had immigration rates of 30\% with a distribution extremely skewed towards less educated immigrants. Immigration rates for the least educated was almost $80 \%$ in Reno and $70 \%$ in Las Vegas. Those rates dropped substantially in the 2000s. While immigration rates in the 1990 s were above $10 \%$ in all the top 20 cities, in the 2000s they were above $10 \%$ only for 7 of them. In terms of composition across education groups, the large cities of California, New York and Florida, such as Los Angeles, San Francisco, Miami and New York City, show much larger immigration rates among more educated groups, especially in the 2000s. To the contrary, large cities of Nevada, Arizona and Texas, such as Austin, Dallas, Las Vegas and Phoenix, show much larger immigration rates among the less educated. However, even for these cities, magnets for less educated immigrants during the 1990s, the composition across education groups was much more balanced in the 2000s. For instance, Las Vegas had an immigration rate among individuals with no diploma of $78 \%$ in the 1990 s and only a rate of $27.4 \%$ among college graduates. The same city experienced immigration rates of $27 \%$ and $22 \%$ for no diploma and college graduates, respectively, in the 2000s. Los Angeles had a net immigration of $-10 \%$ among individuals with no diploma in the 2000s and of $10 \%$ among college graduates. Immigration contributed to increase the share of college educated in that city very substantially.

The recession of the late 2000s in general was associated with lower immigration rates and with a very strong aggregate rebalancing of immigrants across schooling groups. Even cities and states that attracted a huge number of less educated immigrants relative to more educated ones during the 1990s tend to have a relatively balanced composition of net immigrants in the 2000s.

Finally, changes in poverty rates by cities show very large variation and differences. The largest positive changes are still for the group of no diploma or for high school educated during the 2000s, with alarmingly large increases in cities like Atlanta (GA), Fayetville (AR), Phoenix (AZ), RaleighDurham (NC) and Reno (NV). In all those places poverty rates of least educated increased by more than $6 \%$ of the population in the group. Even in the case of metropolitan areas, however, it is impossible to identify any correlation between immigration rates and evolution of poverty rates among the considered metropolitan areas. I will analyze the relation between immigration and actual poverty rates in greater detail throughout the next section. 


\section{Simulated effects on native wages and on poverty rates: US in the 1990s and in the 2000s}

Using the model described in section 2 we simulate the effect of immigrants on wages of natives in eight education-experience groups. Considering the total inflow of immigrants in each cell as a supply shock I assume that, in the long run (10 year period), the adjustment takes place via wage adjustments. Hence, the change in marginal productivity of each type of native worker, in response to the supply shocks, measures the wage effect of immigrants on each of these groups. Considering the changes at the national level, I evaluate the average effect of immigrants on native wages, assuming perfect internal mobility of natives in the long run. Considering states and cities individually, and the specific immigration rates that they received, I simulate the largest possible wage effect imputable to immigrants under the assumption that native workers were not mobile across states or cities. Those simulated effects are likely to be upper bounds of reasonable effects. In fact, if a large local influx of immigrants depresses (or raises) wages substantially, natives could flow in or out to attenuate these effects at least partially. However, if the simulated local wage effects are not too large, they can be reasonable, as small costs of internal migration may prevent full equalization of wages. It is instructive to show these effects. As we will see, in most cases, even these upper bounds are rather small and would not trigger any large native migration in response.

\subsection{Effects of Immigration on Natives Wages}

Figures 2 and 3 show the simulated percentage wage effects of immigration on natives for eight skill groups, nationally, during the periods 1990-2000 and 2000-2009, respectively. The groups are arrayed from young workers with no diploma to old workers with a college degree in increasing

order of schooling. I connected the estimates, in order to provide an easier reading of the relative wage effects across skills. Table A2 in the appendix shows the actual simulated values. Immigration during the 1990s (Figure 2) produced a negative wage impact on the least educated group (around $-2 \%$ ) if we use the most pessimistic configuration of the parameters. In particular, the relatively large inflow of immigrant workers with no diploma is shown to depress wages of natives in the same group if we assume perfect substitutability between native and immigrants and imperfect substitutability between workers with no diploma and high school graduates. However, if I use the preferred configuration of parameters, that allows for imperfect substitutability between native and 
immigrants and perfect substitutability between workers with no diploma and high school graduates (plus a small positive externality of college educated), I obtain a close to zero effect on wages of the least educated workers. With the most favorable configuration of parameters, which allows for an even smaller substitutability immigrant-natives and stronger human capital externalities, the effect of immigrants on the group with no diploma is actually positive $(+0.5 \%)$. In all cases the impact on wages of workers with higher education (some college or more) is positive in the order of $+1 \%$. On average the preferred specification produces a gain for native wage income of $+0.5 \%$ even in the 1990s a decade with much larger inflow of less educated workers. When I consider immigration during the 2000s (Figure 3), the picture is quite positive in terms of wage effects for natives. For all parameter configurations I obtain wage gains for native workers with no diploma or high school diploma between $0.7 \%$ and $1.6 \%$. Only for the most pessimistic configuration the group of old workers with no diploma has essentially no gains and no losses. In all other cases the groups of less educated actually gain. As for highly educated, they essentially have negligible positive wage effects in the preferred and optimistic configuration and small negative effects (around -0.3\%) in the most pessimistic scenario. Hence, the national effects of immigrants on native wages during the 2000s, simulated assuming a national integrated market, were mainly positive for the groups of the least educated individuals, at highest risk of poverty, and mostly negligible for the group of highly educated. Let me emphasize that the biggest role in pushing some effects to be zero rather than positive (for old workers with no diploma) or to be negative rather than zero (for old workers with some college education) is played by the parameter $\sigma_{L L}$ regulating substitutability between workers with no diploma and high school graduates. As soon as I consider the two groups as perfect substitutes I obtain estimates close to those in the preferred specification, even for other parameter values at their "most pessimistic" value.

\subsection{Effects on National Poverty Rates}

I translate the wage effects estimated above into effects on the poverty rates for different demographic groups. I proceed as follows. As the simulated wage effects vary by education and age, I consider the individuals from the Census and ACS in 2000 as well as 2009 and I subtract the education-age specific effect of immigration during 1990-2000 from their wage income in 2000 and 
similarly the effect of immigration during 2000-2009 from their wage income in 20097. This produces the counter-factual wage for each individual in 2000, absent immigration during 1990-2000 and for each individual in 2009, absent immigration during 2000-2009. Then I aggregate the wage income with other sources of income within each family and apply the poverty thresholds (shown in Table A2 of the Appendix) to the new counterfactual total family income. ${ }^{8}$ Some native families will cross the poverty threshold when considering the counterfactual relative to the actual wage. Those will generate differences in native poverty rates with or without immigration. As groups of less educated and young individuals are more concentrated in the proximity of the poverty line it is likely that a given wage change will cause larger effects on poverty for those groups. I documented in Table 2 that women were more susceptible of being in families below the poverty line relative to men. Hence, it is useful to show the effect of immigration on native poverty by education, age and gender groups. Figure 5 and Figure 6 show the simulated effect of immigration in increasing or decreasing native poverty rates across skill groups in the periods 1990-2000 and 2000-2009, respectively. The figures report the changes in poverty rates, as a percentage of the group population, imputed by using the most favorable estimates (red bars) and the most pessimistic ones (blue bars). As a comparison, I also report the actual changes in poverty rates during the corresponding period for each group (green bar). The groups are arrayed from less educated to most educated, distinguishing within each education group between young and old and within each education-age group between women (W) and men (M). Table A3 in the Appendix shows the numerical values of the simulated and actual poverty changes used to produce Figures 5 and 6 .

Three main results emerge very clearly from these figures. First, consistently with the fact that the wage effects of immigration were rather small, the effect of immigration on native poverty are even smaller. When compared with actual poverty changes in the corresponding decade for any

\footnotetext{
${ }^{7}$ In the counterfactual scenario I only consider the wage impact of immigration. If labor supply of natives is not perfectly rigid there may also be effects of immigration on hours worked by natives. Those will amplify the impact of immigrants. However, as the elasticity of labor supply is usually estimated to be between 0 and 0.2 the effect would be quite small.

${ }^{8}$ Notice that for families close to and below the poverty line wage income is a smaller share of total income, relative to the average US family. This is because larger part of their income come from welfare programs. For instance in year 2000 for the average US family $80 \%$ of total income was wage income, while for families below the poverty line only $54 \%$ of total income was from wages.
}

This is an additional reason why the changes in wage income of natives has only small effects on poverty rates. 
group they are one order of magnitude smaller. Even in the case of the most pessimistic wage estimates they cannot explain more than a very small fraction of actual poverty changes. Second, the largest imputed effects of immigration on native poverty are relative to the group of young women with no diploma. These imputed effects range between an increase in poverty of $0.20 \%$, using the most pessimistic estimate in the $1990 \mathrm{~s}$, to a poverty reduction of $0.50 \%$, using the most favorable estimates during the 2000s. In both cases, however, those are very small effects. They do not even get close to explaining the evolution of poverty rates in that group, which experienced a reduction in poverty rates of almost $3 \%$ in the 1990s and then a stunning increase of poverty rates by almost $8 \%$ in the 2000s. Third, consistently with the imputed wage effects, immigration during the 2000s had a poverty-reduction effect on all groups, albeit small. For the groups of less educated (of different age and gender), the effect ranged from a reduction of $0.05 \%$ to a reduction of $0.7 \%$. Unfortunately, the actual poverty rates for these groups rose by values between $3 \%$ and $8 \%$. The most interesting fact is perhaps that the range of simulated effects of immigration on poverty rates, depending on the choice of parameters, is very small and essentially irrelevant to explain actual changes in poverty rates. No matter what our preferred representation of the interactions across skills in the labor market is, as captured by the model's parameters, immigration at the national level does not explain any relevant fraction of the evolution of poverty rates.

To show the aggregate effects of immigration on native poverty rates, Table 8 , aggregates the skill groups and summarizes the effect on native poverty for all U.S. born, for men and women separately, and for two groups with particularly intense exposure to poverty: African American and Hispanic. Considering the evolution during the 2000s, the results shown in Table 8 confirm that immigration had a poverty-reduction effect between $0.07 \%$ and $0.12 \%$ for U.S. natives overall, a bit larger for women (between $0.07 \%$ and $0.13 \%$ ) than for men (between 0.08 and $0.09 \%$ ). African Americans had a poverty reduction effect up to $0.20 \%$, and in particular black women might have experienced up to a $0.24 \%$ reduction in poverty rates due to immigration. The larger effects on black and women is due to their larger presence among young and less educated, the groups at highest risk of poverty. Immigration during the 2000s helped this group the most as it was relatively concentrated among the highly educated, complementary to young less educated. Finally, the simulated poverty reduction for the group of Hispanics, born in the US, is between 0.15 and $0.20 \%$. Interestingly, this is also the only group that actually experienced a decrease in poverty rates during the 2000s (by $0.30 \%$ ). Native blacks and whites had an increase in poverty rates between 1.5 and 
$2 \%$ in the years 2000-2009. Immigration might have been a significant factor in poverty-reduction for native Hispanics (concentrated among less educated) in the 2000s.

The effects found in this section confirm the estimates for the period 1970-2000 by Raphael and Smolensky (2008). They found negligible effects of immigrants on native poverty, due to very small wage effects. Here I extend that analysis to the 2000s and I introduce combinations of parameters that span a larger set of models. I find that actually in the recent decade immigration had a small but consistently positive effect in poverty reduction. I turn now to local effects in States and Metropolitan areas.

\section{Simulated Effects on Native Wages and Poverty in States and MSAs}

The previous section shows that, at the national level, the wage-competition effects of immigration, especially during the 2000s, are simply not strong enough to explain any significant fraction of the actual changes in poverty rates. Highly educated immigrants more than offset the competition of less educated ones and immigration had actually a poverty reduction effect. However, some states and metropolitan areas with large immigration rates certainly received a more unbalanced inflow of immigrants. Some did receive very large shares of less educated immigrants. Assuming that natives did not move in response to immigration, are the local inflows large enough and distributed appropriately across skills and geography to explain differences in changes of native poverty rates across states and metro areas? I look into this question in the present section.

\subsection{Top-Immigration States}

I begin by considering the wage effect of immigrants on the usual eight skill-groups of natives in the top-immigration States, whose trends were described in Tables 4 and 5. Panel 7 shows the percentage wage effects of immigration on natives for each skill group during the period 2000-2009 in the ten states. If I focus on the four bottom groups, which are the more likely to be at risk of poverty, I can emphasize two results. First, when I consider the "preferred" and the "optimistic" scenario estimates, all the wage effects of immigrants on less educated natives are positive or close to 0 , except for Utah, where they range between 0 and $-1 \%$. Second, even when I consider the most pessimistic scenario only for the group of old workers with no diploma, I find significant 
negative effects (in the order of $-2 \%$ to $-4 \%$ ) for some states (Arizona, Colorado, Nevada, Texas and Utah). Third, for highly educated individuals the effects are around 0, with some depressing effect in Florida and New York. Overall, the relatively positive effect of immigration on wages of the least educated, found at the national level, is also confirmed in the large immigration states, with the possible exception for the group of old workers with no diploma, when I consider the most pessimistic estimates. The wage effect of immigration during the 1990s (not reported) were more harmful for wages of the least educated in states as Arizona, Colorado, Nevada or Texas. Still, by the 2000s even for those states the wage effect of immigrants on natives turned mostly positive according to the simulation results.

We can see how these wage effects across states map into effects on the corresponding poverty rates in Figures 8 and 9. These figures show the simulated poverty-rate effects of immigration for each of the four education groups (No diploma, High School Graduates, Some College and College Graduates) in the ten states, using the pessimistic (dark blue), the preferred (medium blue), and the most optimistic (light blue) configuration. I also show the actual change in poverty rates for the education-by-state group in the decade in red. The education groups are always arrayed from the lowest to the highest one for each state. Figure 9 shows the effects in the 1990s. Only the most pessimistic estimates for Arizona, Colorado, Nevada and Texas produce a poverty increase for the least educated group of some significance (around 1\%). For all other states, and for the other simulation scenarios, the poverty changes due to immigrants across top immigration states are less than 0.5\%, even in the 1990s. Moreover in Arizona, Colorado, Nevada and Texas, the actual poverty rates of the least educated during the 1990s (represented by the red columns) exhibit a reduction rather than an increase as predicted by the model. The group of natives with no diploma in Arizona and Colorado experienced a reduction of poverty rates by $2 \%$ or more, and in Texas and Nevada of almost $1 \%$.

The contrast between imputed and actual effects is even more striking in the 2000s. In this decade, immigrants had small poverty-reducing effects for the least educated natives, especially in states like Arizona, California, Florida and New Jersey. As mentioned, this was due to the schooling intensity of immigrants in those states. To the contrary, these groups experienced an increase in poverty rates (red bars) in all states. Moreover, the magnitude of the actual increase in poverty rates was an order of magnitude larger than the reduction effect imputed to immigrants. This lack of explanatory power of the imputed effects, for the actual poverty changes across education 
groups by states, is made very clear by Figure 10. It shows the actual changes in poverty rates of four education groups in ten states, pooling the 1990-2000 and 2000-2009 decades versus the corresponding changes imputed to immigrants, using the general equilibrium simulations and the preferred parameter specification. While the dependent variable had a very large range of variation, showing large state-specific and group-specific changes in poverty trends, the independent variable had almost no variation, in comparison. The simulated values cluster around zero and show no (or if anything negative) correlation with the dependent variable.

\subsection{Top-Immigration Metropolitan Areas}

To complete the picture, I perform the same analysis considering the twenty top-immigration metropolitan areas described in Tables 6 and 7. Metropolitan areas are small enough that sometimes local immigration rates over a decade can be extremely high, and also extremely skewed towards some groups. This provides large cross-city variation in immigration and increases the potential explanatory power of this variable in terms of poverty effects. On the down side, however, the measurement error may be more severe at the MSA level in several variables and simulating the local wage effects under the scenario of no mobility of natives across metro areas seems quite extreme.

Focusing on the decade 2000-2009, the wage effect of immigration by skill group in some cities was relatively large, at least compared to the national one. In some cities and groups the wages of natives decreased by $4-5 \%$ due to immigration, according to our model. However, in the same cities the wage of other groups increased by $6-10 \%$ due to immigrants. The most likely situation for the top 20 cities considered was that the wage of less educated actually increased because of immigration. This is illustrated in Figure 11, which shows the imputed percentage wage effect of immigrants on natives by skill, using the general equilibrium model for the period 2000-2009. In cities such as McAllen (TX), Yuma (AZ) and Raleigh-Durham (NC), our simulations predict that immigration should have increased wages of less educated individuals by $6-8 \%$, provided that natives did not move during the 2000-2009 period. Similarly, assuming lack of mobility of natives and the most pessimistic parameter configuration, the least educated citizens in cities such as Reno, Las Vegas and Austin should have experienced a 1.5\% to $2 \%$ increase in poverty rates because of immigration during the 1990-2000 period. These are non negligible values. Figure 12, however, puts them into perspective by showing the actual changes in poverty rates (red columns) together 
with the imputed effects due to immigration (blue bars) for the four schooling groups in the twenty MSAs considered. While cities like Huston, Las Vegas and Reno had actual and imputed changes in poverty rates of comparable magnitude, in general, the actual changes of poverty rates were much larger and much more variable than the imputed ones.

For the changes in the 2000-2009 period, Figure 13 shows the imputed changes in poverty rates due to immigration (in blue) and the actual ones (in red). Except for Fayetville, AZ, (in which immigration explains a non-negligible share of the actual increase in poverty) the simulations predict a reduction in poverty rates due to immigration for all the other cities. However, these MSAs experienced increases in poverty rates during 2000-2009. Thus, by plotting actual (vertical axis) versus imputed (horizontal axis) poverty rates, Figure 14 shows the inability of immigration to explain the changes and variation in poverty rates, even at the metropolitan area level.

\section{Conclusions}

The most recent assessments of the wage impact of immigrants in the US (Card 2009, Ottaviano and Peri forthcoming) agree that there is little evidence of a large wage competition effect on natives. In this study, I focus on a specific consequence of the wage competition of immigrants: the resulting increase in native poverty due to a negative income effect on individuals who are already near the poverty line. The poverty rate, while somewhat arbitrary, is a useful measure of the percentage of individuals in a very weak and vulnerable situation and it is used as reference in several mean-tested welfare programs. Hence, the impact of immigration in increasing or decreasing native poverty is an interesting measure, possibly also affecting the size of welfare programs towards natives.

I assessed how the wage competition of immigrants, evaluated using a general equilibrium model of the labor market, affected native poverty rates. I find that there was essentially no effect of immigration on poverty at the national level during the whole period 1990-2009. To be more specific, I am able to construct very small poverty-increasing effects of immigration during the 1990s by adopting rather extreme parameter values in the simulations. In the 2000s, even the most pessimistic simulations deliver poverty-reduction effects of immigrants. This is because immigration in the 2000s has been quite skill-intensive with a much larger immigration rate among college educated than among any other group.

At the state and city level, a more nuanced picture confirms these findings. Even focussing on 
top immigration states and metropolitan areas, using the most reasonable parameter configuration, I only detect very small wage effects on natives. Considering immigration in the 2000s, these effects are actually positive for wages of less educated individuals and, in general, poverty-reducing even across large immigration states and metropolitan areas. What is also striking is the complete inability of the immigration-imputed effects (even with the most extreme assumptions of parameters and native mobility) to explain the magnitude and the variance in poverty changes across education groups and states or cities. The impact of immigrants via wage competition is simply too small and not correlated enough to actual income, to be a valid candidate to explain a significant part of poverty changes in the US. Moreover, highly educated immigration may actually reduce native poverty rates. 


\section{References}

[1] Acemoglu, Daron, and Joshua Angrist (2000). How large are human capital externalities? Evidence from compulsory schooling laws. NBER Macroeconomic Annual 15.

[2] Altonji, Joseph G. and David Card, (1989). "The Effects of Immigration on the Labor Market Outcomes of Natives," NBER Working Papers 3123, National Bureau of Economic Research, Cambridge, Ma.

[3] Altonji, Joseph G. and Card, David (1991). "The Effects of Immigration on the Labor Market Outcomes of Less-skilled Natives," NBER Chapters, in: Immigration, Trade and the Labor Market, pages 201-234. National Bureau of Economic Research, Inc.

[4] Angrist, Joshua (1995). The Economic Returns to Schooling in the West Bank and Gaza Strip. American Economic Review 85 (5): 1065-1087.

[5] Borjas, George (2003). " The Labor Demand Curve is Downward Sloping: Reexamining the Impact of Immigration on the Labor Market" Quarterly Journal of Economics, 118, 1335-1374.

[6] Borjas, George, Richard Freeman, and Larry Katz (1997). "How Much Do Immigration and Trade Affect Labor Market Outcomes?" Brookings Papers on Economic Activity 1997 (1), $1-90$.

[7] Borjas, George, and Lawrence Katz (2007). The Evolution of the Mexican-Born Workforce in the United States. In: Borjas, George (Ed), Mexican Immigration to the United States National Bureau of Economic Research Conference Report, Cambridge, MA.

[8] Borjas, George, Jeffrey Grogger, and Gordon Hanson (2008). Imperfect Substitution between Immigrants and Natives: A Reappraisal. National Bureau of Economic Research, Working Paper \# 13887, Cambridge, MA.

[9] Card, David (2009). Immigration and inequality. American Economic Review 99 (2): 1-21.

[10] Card, David, and Thomas Lemieux (2001). Can Falling Supply Explain the Rising Returns to College for Younger Men? A Cohort Based Analysis. Quarterly Journal of Economics 116 (2): 705-746. 
[11] Ciccone Antonio and Giovanni Peri (2005). "Long-Run Substitutability between More and Less Educated Workers: Evidence from U.S. States 1950-1990" (with Antonio Ciccone) Review of Economics and Statistics, Vol. 87, Issue 4, pages 652-663.

[12] Docquier Frederic, Caglar Ozden and Giovanni Peri (2010). " The Wage effect of Immigration and Emigration" , NBER WP \#16646, December 2010.

[13] Goldin, Claudia and Larry Katz (2008). " The Race Between Education and Technology." , Harvard University Press, Cambridge, MA, 2008.

[14] Iranzo, Susana, and Giovanni Peri (2009). Migration and Trade: Theory with an Application to the Eastern-Western European Integration. CReAM Discussion Paper Series 0905.

[15] Johnson, George E. (1970). The Demand for Labor by Educational Category. Southern Economic Journal, 37: 190-203.

[16] Katz, Larry, and Kevin Murphy (1992). Changes in Relative Wages 1963-1987: Supply and Demand Factors. Quarterly Journal of Economics 107 (1): 35-78.

[17] Manacorda Marco, Alan Manning and John Wadsworth (Forthcoming). " The Impact of Immigration on the Structure of Wages: Theory and Evidence from Britain" Journal of European Economic Association, forthcoming.

[18] Moretti, Enrico (2004a). Estimating the Social Return to Higher Education: Evidence from Longitudinal and Repeated Cross-Sectional Data. Journal of Econometrics 121 (1), 175-212.

[19] Moretti, Enrico (2004b). Workers' Education, Spillovers and Productivity: Evidence from Plant-Level Production Functions. American Economic Review 94 (3), 656-690.

[20] Ottaviano, Gianmarco L.P., and Giovanni Peri (forthcoming). Rethinking the Effects of Immigration on Wages. Journal of the European Economic Association (forthcoming).

[21] Raphael Steven and Eugene Smolensky (2008). "Immigration and Poverty in the United States" UC Berkeley Working Paper, April 2008.

[22] Ramsey, Frank (1928). A Mathematical Theory of Saving. Economic Journal 38 (152): 543559. 
[23] Solow, Robert (1956). A Contribution to the Theory of Economic Growth. Quarterly Journal of Economics 70 (1): 65-94.

[24] Welch, Finis (1979). Effects of Cohort Size on Earnings: The Baby Boom Babies Financial Boost. Journal of Political Economy 87, no. 5: 65-97. 


\section{A Effect on Native Wages}

Considering the notation of section 2 I define the percentage change in the immigrant population in schooling group $k$ age group $j$ and in period $t$ as $\frac{\Delta I_{k j t}}{I_{k j t}}$. I also call $s_{I k j t}$ the share of the total wage bill going to immigrants of schooling $k$ and age $j$ and similarly $s_{k j t}$ is the share to all workers (native and immigrants) with skills $k j$ and $s_{k t}$ the wage share of workers with schooling $k$. The overall percentage effect of the inflow of immigrants on the wage of native workers of education $k$ and age $j$ is given by:

$$
\begin{aligned}
\left(\frac{\Delta w_{k j t}}{w_{k j t}}\right)^{\text {Total }}= & \frac{1}{\sigma_{H L}} \sum_{k \in H, L} \sum_{j \in Y, O}\left(s_{I k j t} \frac{\Delta I_{k j t}}{I_{k j t}}\right) \\
& +\left(\frac{1}{\sigma_{Y O}}-\frac{1}{\sigma_{H L}}\right)\left(\frac{1}{s_{k t}}\right) \sum_{j \in Y, O}\left(s_{I k j t} \frac{\Delta I_{k j t}}{I_{k j t}}\right) \\
& +\left(\frac{1}{\sigma_{I N}}-\frac{1}{\sigma_{Y O}}\right)\left(\frac{1}{s_{k j t}}\right)\left(s_{I k j t} \frac{\Delta F_{b k j t}}{F_{b k j t}}\right) \\
& +\lambda\left(\frac{\Delta h_{t}}{h_{t}}\right)_{\text {immigration }}
\end{aligned}
$$

The term $\frac{1}{\sigma_{H L}} \sum_{k \in H, L} \sum_{j \in Y, O}\left(s_{I k j t} \frac{\Delta I_{k j t}}{I_{k j t}}\right)$ captures the aggregate wage effect from immigration in all cells, the term $\left(\frac{1}{\sigma_{Y O}}-\frac{1}{\sigma_{H L}}\right)\left(\frac{1}{s_{k t}}\right) \sum_{j \in Y, O}\left(s_{I k j t} \frac{\Delta I_{k j t}}{I_{k j t}}\right)$ is the extra-competition effect due to immigration in the same education group and the term $\left(\frac{1}{\sigma_{I N}}-\frac{1}{\sigma_{Y O}}\right)\left(\frac{1}{s_{k j t}}\right)\left(s_{I k j t} \frac{\Delta F_{b k j t}}{F_{b k j t}}\right)$ is the further competition effect on native wages from immigrants in the same education and experience group. The term $\left(\frac{\Delta h_{t}}{h_{t}}\right)_{\text {immigration }}$ captures the change in the share of college educated individuals due to immigration and it contributes via the externality to the overall wage effect. ${ }^{9}$

\footnotetext{
${ }^{9}$ In the simulations that include a further nesting for two subgroups within the less educated the formula incldes and extra term.
} 
Table 1

Parameterization of the model

\begin{tabular}{lccc}
\hline \hline Parameter Estimates & Most Pessimistic & Preferred Estimates & Most Favorable \\
\hline $\begin{array}{l}\sigma_{\mathrm{HL}}, \text { Elasticity between more } \\
\text { and less educated }\end{array}$ & 1.5 & 1.75 & 2.0 \\
\hline $\begin{array}{l}\sigma_{\mathrm{LL}}: \text { Elasticity between } \\
\text { subgroups with no degree and } \\
\text { high school graduates }\end{array}$ & 10 & infinity & infinity \\
\hline $\begin{array}{l}\sigma_{\mathrm{I}}: \text { Elasticity between } \\
\text { immigrants and natives }\end{array}$ & infinity & 20 & 12 \\
\hline$\lambda:$ College share externality & 0.0 & 0.45 & 0.75 \\
\hline \hline
\end{tabular}

Note: The table summarizes the values of the parameters taken from the previous literature and used in our simulation of wage effects of immigrants and emigrants. 
Table 2:

Immigration rates in the 1990's and 2000's by schooling, Age and Gender: National Data

\begin{tabular}{lllll}
\hline Schooling Group & Age/Experience & Gender & \multicolumn{2}{c}{ Net Immigration rates } \\
\hline No Diploma & & & $1990-2000$ & $2000-2009$ \\
& Young & Women & $11.4 \%$ & $-3.0 \%$ \\
& Young & Men & $15.8 \%$ & $-2.4 \%$ \\
& Old & Women & $8.6 \%$ & $8.2 \%$ \\
High School Graduate & Old & Men & $10.3 \%$ & $11.2 \%$ \\
& Young & Women & $6.6 \%$ & $-0.3 \%$ \\
& Young & Men & $8.0 \%$ & $1.3 \%$ \\
Total Less Educated & Old & Women & $5.4 \%$ & $3.5 \%$ \\
\hline Some College Education & Old & Men & $7.7 \%$ & $4.8 \%$ \\
& & & $\mathbf{7 . 1 \%}$ & $\mathbf{2 . 4 \%}$ \\
\hline & Young & Women & $1.3 \%$ & $2.3 \%$ \\
College Graduate or More & Young & Men & $0.8 \%$ & $2.7 \%$ \\
& Old & Women & $2.9 \%$ & $5.6 \%$ \\
& Old & Men & $3.3 \%$ & $5.2 \%$ \\
Toung & Woung & Men & $8.3 \%$ & $5.5 \%$ \\
\hline & Old & Women & $6.5 \%$ & $3.8 \%$ \\
\hline
\end{tabular}

Note: Net Immigration rates for a group are measured as the net inflows of immigrants in the group during the period, relative to the population (natives + immigrants) in the group, at the beginning of the period. Young individuals are those with less than 20 years of potential experience in the labor market. Potential experience is (Age-years of schooling-6). The data are from the US Census 1990, 2000 and ACS 2009. The population considered covers non- institutionalized individuals in working age (16 to 65). 
Table 3:

Adult poverty rates (16-65) among U.S. born, 1990's and 2000', by schooling, Age and Gender: National Data

\begin{tabular}{|c|c|c|c|c|c|c|}
\hline \multirow[t]{2}{*}{ Schooling Group } & \multirow[t]{2}{*}{ Age/Experience } & \multirow[t]{2}{*}{ Gender } & \multicolumn{4}{|c|}{ Poverty Rates } \\
\hline & & & 2000 & 2009 & $\begin{array}{c}\text { Change } \\
1990-2000\end{array}$ & $\begin{array}{c}\text { Change } \\
\text { 2000-2009 }\end{array}$ \\
\hline \multirow[t]{4}{*}{ No Diploma } & Young & Women & $34.5 \%$ & $42.4 \%$ & $8.3 \%$ & $7.9 \%$ \\
\hline & Young & Men & $20.0 \%$ & $26.1 \%$ & $4.9 \%$ & $6.1 \%$ \\
\hline & Old & Women & $26.6 \%$ & $33.5 \%$ & $-6.9 \%$ & $6.9 \%$ \\
\hline & Old & Men & $19.2 \%$ & $24.3 \%$ & $-9.5 \%$ & $5.1 \%$ \\
\hline \multirow[t]{4}{*}{ High School Graduate } & Young & Women & $17.0 \%$ & $23.9 \%$ & $-5.5 \%$ & $6.8 \%$ \\
\hline & Young & Men & $9.5 \%$ & $13.1 \%$ & $-1.0 \%$ & $3.6 \%$ \\
\hline & Old & Women & $8.9 \%$ & $11.7 \%$ & $-2.6 \%$ & $2.8 \%$ \\
\hline & Old & Men & $7.2 \%$ & $9.4 \%$ & $-3.1 \%$ & $2.2 \%$ \\
\hline Total Less Educated & & & $16.0 \%$ & $22.0 \%$ & $1.5 \%$ & $6.0 \%$ \\
\hline \multirow[t]{4}{*}{ Some College Education } & Young & Women & $11.0 \%$ & $16.5 \%$ & $-3.3 \%$ & $5.5 \%$ \\
\hline & Young & Men & $7.9 \%$ & $11.3 \%$ & $-0.7 \%$ & $3.4 \%$ \\
\hline & Old & Women & $5.6 \%$ & $7.9 \%$ & $-2.1 \%$ & $2.4 \%$ \\
\hline & Old & Men & $4.4 \%$ & $6.5 \%$ & $-3.3 \%$ & $2.0 \%$ \\
\hline \multirow[t]{4}{*}{ College Graduate or More } & Young & Women & $3.5 \%$ & $4.6 \%$ & $3.7 \%$ & $1.0 \%$ \\
\hline & Young & Men & $3.2 \%$ & $4.0 \%$ & $2.9 \%$ & $0.8 \%$ \\
\hline & Old & Women & $2.5 \%$ & $3.3 \%$ & $2.8 \%$ & $0.8 \%$ \\
\hline & Old & Men & $2.2 \%$ & $3.0 \%$ & $1.3 \%$ & $0.8 \%$ \\
\hline Total More Educated & & & $4.2 \%$ & $5.4 \%$ & $0.3 \%$ & $1.2 \%$ \\
\hline Total U.S. Born & & & $12 \%$ & $16 \%$ & $1.1 \%$ & $4 \%$ \\
\hline
\end{tabular}

Note: Poverty rates are equal to the percentage of people in the group below the Federal Poverty line. The groups are defined as in Table 1. 
Table 4

Immigration rates by schooling group in 10 top-immigration states, 1990-2000 and 2000-2009

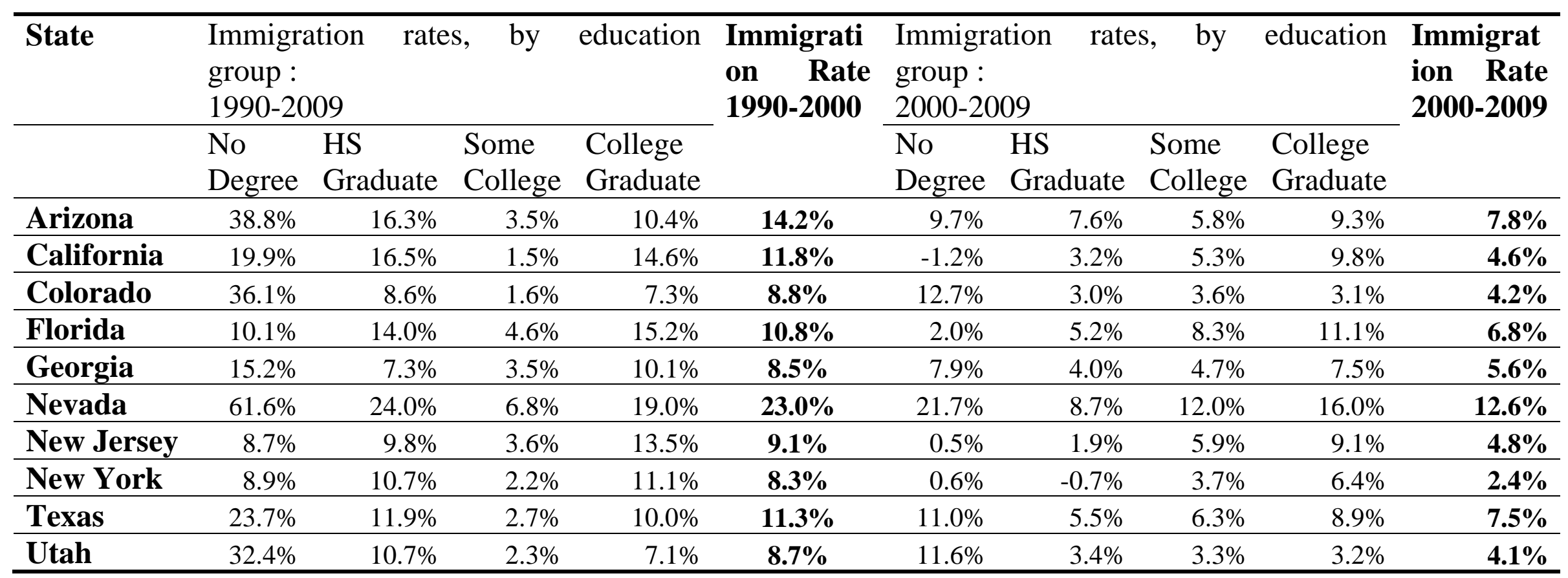

Notes: The top immigration states included in the Table are the 9 states with the highest immigration rate 1990-2006 and the six states with the highest share of foreign-born as of 2009. 


\section{Table 5}

\section{Change in Native Poverty rates by schooling group in 10 top-immigration states, 1990-2000 and 2000-2009}

\begin{tabular}{|c|c|c|c|c|c|c|c|c|c|c|}
\hline \multirow[t]{3}{*}{$\overline{\text { State }}$} & \multicolumn{4}{|c|}{$\begin{array}{l}\text { Change in native poverty rates } \\
1990-2000\end{array}$} & \multirow{3}{*}{$\begin{array}{l}\text { Overall } \\
\text { change in } \\
\text { native } \\
\text { poverty rate } \\
1990-2000\end{array}$} & \multicolumn{4}{|c|}{$\begin{array}{l}\text { Change in native poverty rates, } \\
2000-2009\end{array}$} & $\begin{array}{l}\text { Overall } \\
\text { change in } \\
\text { native } \\
\text { poverty } \\
\text { rate 2000- } \\
2009\end{array}$ \\
\hline & No & HS & Some & College & & No & $\mathrm{HS}$ & Some & College & \\
\hline & Degree & Graduate & College & Graduate & & Degree & Graduate & College & Graduate & \\
\hline Arizona & $-2.03 \%$ & $-1.69 \%$ & $-1.47 \%$ & $-0.73 \%$ & $-1.99 \%$ & $5.23 \%$ & $2.86 \%$ & $3.64 \%$ & $1.21 \%$ & $2.46 \%$ \\
\hline California & $5.88 \%$ & $2.51 \%$ & $1.49 \%$ & $0.46 \%$ & $1.72 \%$ & $1.40 \%$ & $0.99 \%$ & $2.19 \%$ & $0.77 \%$ & $0.84 \%$ \\
\hline Colorado & $-3.32 \%$ & $-2.06 \%$ & $-0.86 \%$ & $-0.74 \%$ & $-1.97 \%$ & $7.12 \%$ & $3.85 \%$ & $2.80 \%$ & $1.26 \%$ & $2.43 \%$ \\
\hline Florida & $1.70 \%$ & $0.86 \%$ & $0.72 \%$ & $0.53 \%$ & $0.23 \%$ & $5.58 \%$ & $3.95 \%$ & $3.73 \%$ & $1.00 \%$ & $2.74 \%$ \\
\hline Georgia & $1.11 \%$ & $0.42 \%$ & $0.68 \%$ & $0.40 \%$ & $-0.63 \%$ & $7.86 \%$ & $4.23 \%$ & $3.38 \%$ & $1.36 \%$ & $2.82 \%$ \\
\hline Nevada & $1.76 \%$ & $-0.12 \%$ & $-0.79 \%$ & $-0.44 \%$ & $-0.38 \%$ & $1.84 \%$ & $1.65 \%$ & $2.76 \%$ & $1.12 \%$ & $1.42 \%$ \\
\hline New Jersey & $5.14 \%$ & $1.93 \%$ & $1.22 \%$ & $0.55 \%$ & $1.12 \%$ & $3.53 \%$ & $1.36 \%$ & $1.84 \%$ & $0.20 \%$ & $0.56 \%$ \\
\hline New York & $5.56 \%$ & $2.93 \%$ & $1.60 \%$ & $0.49 \%$ & $1.40 \%$ & $1.76 \%$ & $1.13 \%$ & $1.82 \%$ & $0.77 \%$ & $0.21 \%$ \\
\hline Texas & $-3.22 \%$ & $-1.61 \%$ & $-0.47 \%$ & $-0.41 \%$ & $-2.05 \%$ & $2.02 \%$ & $2.50 \%$ & $2.62 \%$ & $0.77 \%$ & $1.26 \%$ \\
\hline Utah & $-4.69 \%$ & $-1.31 \%$ & $-1.02 \%$ & $-1.09 \%$ & $-1.86 \%$ & $7.13 \%$ & $1.83 \%$ & $2.98 \%$ & $0.89 \%$ & $2 . .55 \%$ \\
\hline
\end{tabular}

Notes: The top immigration states as in table 5. 
Table 6

Immigration rates by schooling group in 20 top-immigration metropolitan areas, 1990-2000 and 2000-2009

\begin{tabular}{|c|c|c|c|c|c|c|c|c|c|c|}
\hline \multirow[t]{3}{*}{ State } & \multicolumn{2}{|c|}{$\begin{array}{l}\text { Immigration } \\
\text { group : } \\
\text { 1990-2009 }\end{array}$} & tes, & education & \multirow{3}{*}{$\begin{array}{l}\text { Total } \\
\text { Immigrat } \\
\text { ion Rate } \\
1990- \\
2000\end{array}$} & \multicolumn{4}{|c|}{$\begin{array}{l}\text { Immigration rates, by education group : } \\
\text { 2000-2009 }\end{array}$} & \multirow[t]{3}{*}{$\begin{array}{l}\text { Total } \\
\text { Immigrati } \\
\text { on Rate } \\
\text { 2000-2009 }\end{array}$} \\
\hline & No & $\mathrm{HS}$ & Some & College & & No & HS & Some & College & \\
\hline & $\begin{array}{l}\text { Degre } \\
\text { e }\end{array}$ & Graduate & College & Graduate & & Degree & Graduate & College & Graduate & \\
\hline Atlanta, GA & $42.1 \%$ & $16.9 \%$ & $6.2 \%$ & $14.3 \%$ & $16.0 \%$ & $14.2 \%$ & $7.1 \%$ & $7.4 \%$ & $9.1 \%$ & $8.6 \%$ \\
\hline Austin, TX & $61.6 \%$ & $19.9 \%$ & $4.1 \%$ & $14.2 \%$ & $17.6 \%$ & $32.6 \%$ & $8.7 \%$ & $4.7 \%$ & $9.7 \%$ & $10.9 \%$ \\
\hline Dallas-Fort Worth, TX & $46.8 \%$ & $17.2 \%$ & $3.5 \%$ & $11.4 \%$ & $16.3 \%$ & $18.5 \%$ & $7.8 \%$ & $6.2 \%$ & $9.2 \%$ & $9.7 \%$ \\
\hline Fayetteville, AR & $67.9 \%$ & $16.7 \%$ & $6.0 \%$ & $15.4 \%$ & $22.2 \%$ & $34.0 \%$ & $6.0 \%$ & $5.7 \%$ & $2.2 \%$ & $9.2 \%$ \\
\hline Fort Lauderdale-Hollywood, FL & $20.2 \%$ & $29.5 \%$ & $16.5 \%$ & $32.1 \%$ & $24.7 \%$ & $4.8 \%$ & $7.5 \%$ & $11.6 \%$ & $19.6 \%$ & $11.3 \%$ \\
\hline Houston-Brazoria, TX & $36.4 \%$ & $18.4 \%$ & $4.1 \%$ & $14.0 \%$ & $16.8 \%$ & $17.0 \%$ & $9.3 \%$ & $11.8 \%$ & $11.7 \%$ & $11.9 \%$ \\
\hline Las Vegas, NV & $78.1 \%$ & $31.7 \%$ & $9.7 \%$ & $27.4 \%$ & $30.8 \%$ & $27.3 \%$ & $11.3 \%$ & $14.3 \%$ & $22.1 \%$ & $16.2 \%$ \\
\hline Los Angeles-Long Beach, CA & $14.1 \%$ & $18.2 \%$ & $1.0 \%$ & $14.0 \%$ & $11.2 \%$ & $-10.8 \%$ & $0.6 \%$ & $6.3 \%$ & $10.3 \%$ & $1.7 \%$ \\
\hline McAllen-Edinburg, TX & $33.4 \%$ & $35.1 \%$ & $11.5 \%$ & $29.4 \%$ & $29.5 \%$ & $8.6 \%$ & $12.0 \%$ & $22.2 \%$ & $28.6 \%$ & $14.1 \%$ \\
\hline Miami-Hialeah, FL & $0.7 \%$ & $35.4 \%$ & $2.5 \%$ & $28.3 \%$ & $17.2 \%$ & $-18.5 \%$ & $2.3 \%$ & $13.9 \%$ & $17.0 \%$ & $4.0 \%$ \\
\hline New York- N.E. NJ & $12.5 \%$ & $16.2 \%$ & $4.3 \%$ & $15.9 \%$ & $12.6 \%$ & $-1.2 \%$ & $-0.7 \%$ & $5.9 \%$ & $8.4 \%$ & $3.4 \%$ \\
\hline Orlando, FL & $21.5 \%$ & $17.3 \%$ & $7.5 \%$ & $15.6 \%$ & $14.4 \%$ & $10.1 \%$ & $8.5 \%$ & $12.2 \%$ & $10.7 \%$ & $10.2 \%$ \\
\hline Phoenix, AZ & $60.6 \%$ & $20.4 \%$ & $3.9 \%$ & $12.3 \%$ & $18.1 \%$ & $13.3 \%$ & $10.2 \%$ & $6.9 \%$ & $11.1 \%$ & $10.0 \%$ \\
\hline Raleigh-Durham, NC & $60.4 \%$ & $17.5 \%$ & $5.5 \%$ & $16.2 \%$ & $18.1 \%$ & $22.9 \%$ & $4.8 \%$ & $7.3 \%$ & $8.9 \%$ & $8.9 \%$ \\
\hline Reno, NV & $89.5 \%$ & $34.8 \%$ & $8.7 \%$ & $19.6 \%$ & $29.7 \%$ & $13.5 \%$ & $4.7 \%$ & $7.5 \%$ & $4.9 \%$ & $6.6 \%$ \\
\hline Riverside-S. Bernardino, CA & $33.3 \%$ & $17.5 \%$ & $2.4 \%$ & $13.2 \%$ & $14.6 \%$ & $17.8 \%$ & $10.9 \%$ & $11.1 \%$ & $20.1 \%$ & $13.6 \%$ \\
\hline San Francisco-Oakland-CA & $26.6 \%$ & $16.1 \%$ & $1.6 \%$ & $17.3 \%$ & $12.8 \%$ & $0.8 \%$ & $3.1 \%$ & $1.8 \%$ & $7.4 \%$ & $4.1 \%$ \\
\hline Sarasota, FL & $44.5 \%$ & $17.5 \%$ & $8.0 \%$ & $15.9 \%$ & $17.5 \%$ & $5.0 \%$ & $5.7 \%$ & $6.6 \%$ & $11.7 \%$ & $7.2 \%$ \\
\hline Stamford, CT & $97.0 \%$ & $63.0 \%$ & $24.9 \%$ & $56.5 \%$ & $55.3 \%$ & $4.0 \%$ & $0.5 \%$ & $9.6 \%$ & $5.2 \%$ & $4.7 \%$ \\
\hline Yuma, AZ & $44.4 \%$ & $27.3 \%$ & $9.9 \%$ & $8.0 \%$ & $25.3 \%$ & $2.0 \%$ & $6.6 \%$ & $3.9 \%$ & $25.5 \%$ & $6.6 \%$ \\
\hline
\end{tabular}

Notes: The top immigration metropolitan areas included in Table 5 are the 16 metro areas with the highest immigration rate $1990-2009$ and the four largest Metro areas with share of foreign-born above $30 \%$ 
Table 7

Change in Native Poverty rates by schooling group in $\mathbf{2 0}$ top-immigration metropolitan areas

\begin{tabular}{|c|c|c|c|c|c|c|c|c|c|c|}
\hline \multirow[t]{3}{*}{ State } & \multicolumn{2}{|c|}{$\begin{array}{l}\text { Change in Native } \\
\text { education group : } \\
\text { 1990-2009 }\end{array}$} & \multirow{3}{*}{$\begin{array}{l}\text { Poverty } \\
\text { Some } \\
\text { College }\end{array}$} & \multirow{3}{*}{$\begin{array}{c}\text { Rates, by } \\
\text { College } \\
\text { Graduate }\end{array}$} & \multirow{3}{*}{$\begin{array}{l}\text { Change } \\
\text { in native } \\
\text { poverty } \\
\text { rate } \\
1990- \\
2000\end{array}$} & \multicolumn{2}{|c|}{$\begin{array}{l}\text { Change in Native } \\
\text { education group : } \\
2000-2009\end{array}$} & \multirow{3}{*}{$\begin{array}{l}\text { Poverty } \\
\text { Some } \\
\text { College }\end{array}$} & \multirow{3}{*}{$\begin{array}{l}\text { rates, by } \\
\text { College } \\
\text { Graduate }\end{array}$} & \multirow{3}{*}{$\begin{array}{l}\text { Change in } \\
\text { native } \\
\text { poverty } \\
\text { rate } 2000 \text { - } \\
2009\end{array}$} \\
\hline & No & HS & & & & No & HS & & & \\
\hline & Degree & Graduate & & & & Degree & Graduate & & & \\
\hline Atlanta, GA & $-0.36 \%$ & $-0.56 \%$ & $0.41 \%$ & $0.39 \%$ & $-0.02 \%$ & $8.64 \%$ & $4.28 \%$ & $3.23 \%$ & $1.50 \%$ & $3.41 \%$ \\
\hline Austin, TX & $-9.89 \%$ & $-4.22 \%$ & $-1.45 \%$ & $-1.14 \%$ & $-2.76 \%$ & $3.84 \%$ & $3.05 \%$ & $2.76 \%$ & $0.79 \%$ & $2.08 \%$ \\
\hline Dallas-Fort Worth, TX & $-1.67 \%$ & $-1.39 \%$ & $-0.62 \%$ & $-0.38 \%$ & $-0.93 \%$ & $4.94 \%$ & $3.67 \%$ & $2.90 \%$ & $0.59 \%$ & $2.59 \%$ \\
\hline Fayetteville, AR & $-3.68 \%$ & $0.43 \%$ & $-5.49 \%$ & $-0.22 \%$ & $-1.47 \%$ & $12.26 \%$ & $4.79 \%$ & $0.43 \%$ & $-2.32 \%$ & $2.28 \%$ \\
\hline $\begin{array}{l}\text { Fort Lauderdale-Hollywood, } \\
\text { FL }\end{array}$ & $3.08 \%$ & $1.60 \%$ & $1.14 \%$ & $1.07 \%$ & $1.48 \%$ & $1.74 \%$ & $4.76 \%$ & $2.71 \%$ & $0.63 \%$ & $2.73 \%$ \\
\hline Houston-Brazoria, $\mathrm{TX}$ & $-1.82 \%$ & $-1.04 \%$ & $0.14 \%$ & $-0.23 \%$ & $-0.63 \%$ & $1.82 \%$ & $0.77 \%$ & $1.73 \%$ & $0.56 \%$ & $1.07 \%$ \\
\hline Las Vegas, NV & $2.08 \%$ & $-0.79 \%$ & $-1.18 \%$ & $-0.41 \%$ & $-0.56 \%$ & $-0.06 \%$ & $0.47 \%$ & $2.73 \%$ & $1.93 \%$ & $1.42 \%$ \\
\hline Los Angeles-Long Beach, CA & $6.72 \%$ & $3.50 \%$ & $2.19 \%$ & $0.90 \%$ & $2.60 \%$ & $-0.82 \%$ & $-0.91 \%$ & $1.74 \%$ & $0.42 \%$ & $0.33 \%$ \\
\hline McAllen-Edinburg, TX & $-8.14 \%$ & $-3.04 \%$ & $-1.23 \%$ & $0.19 \%$ & $-3.44 \%$ & $1.03 \%$ & $1.73 \%$ & $-0.23 \%$ & $0.58 \%$ & $0.87 \%$ \\
\hline Miami-Hialeah, FL & $1.86 \%$ & $2.64 \%$ & $0.92 \%$ & $1.12 \%$ & $1.72 \%$ & $2.58 \%$ & $2.31 \%$ & $2.47 \%$ & $-0.01 \%$ & $1.70 \%$ \\
\hline New York- N.E. NJ & $6.17 \%$ & $3.08 \%$ & $1.77 \%$ & $0.45 \%$ & $2.19 \%$ & $0.40 \%$ & $0.36 \%$ & $1.51 \%$ & $0.72 \%$ & $0.76 \%$ \\
\hline Orlando, FL & $3.35 \%$ & $1.60 \%$ & $0.87 \%$ & $0.25 \%$ & $1.26 \%$ & $3.13 \%$ & $3.64 \%$ & $4.77 \%$ & $1.34 \%$ & $3.28 \%$ \\
\hline Phoenix, AZ & $-1.41 \%$ & $-1.79 \%$ & $-1.67 \%$ & $-0.45 \%$ & $-1.37 \%$ & $6.00 \%$ & $3.75 \%$ & $3.64 \%$ & $1.24 \%$ & $3.18 \%$ \\
\hline Raleigh-Durham, NC & $-0.02 \%$ & $1.13 \%$ & $1.96 \%$ & $0.41 \%$ & $0.95 \%$ & $9.12 \%$ & $3.35 \%$ & $4.26 \%$ & $1.18 \%$ & $2.95 \%$ \\
\hline Reno, NV & $-3.16 \%$ & $1.24 \%$ & $-1.82 \%$ & $-1.61 \%$ & $-0.65 \%$ & $8.67 \%$ & $3.01 \%$ & $3.07 \%$ & $-1.61 \%$ & $2.08 \%$ \\
\hline Riverside-S. Bernardino, CA & $6.01 \%$ & $2.83 \%$ & $1.70 \%$ & $0.94 \%$ & $2.54 \%$ & $-0.40 \%$ & $1.35 \%$ & $1.59 \%$ & $1.16 \%$ & $1.23 \%$ \\
\hline San Francisco-Oakland-CA & $4.25 \%$ & $0.34 \%$ & $0.76 \%$ & $0.19 \%$ & $0.59 \%$ & $5.55 \%$ & $1.53 \%$ & $2.98 \%$ & $0.90 \%$ & $1.81 \%$ \\
\hline Sarasota, FL & $4.63 \%$ & $1.20 \%$ & $1.11 \%$ & $1.03 \%$ & $1.47 \%$ & $4.36 \%$ & $5.21 \%$ & $5.56 \%$ & $2.97 \%$ & $4.68 \%$ \\
\hline Stamford, CT & $4.14 \%$ & $2.10 \%$ & $2.21 \%$ & $0.57 \%$ & $1.33 \%$ & $2.26 \%$ & $3.98 \%$ & $2.15 \%$ & $0.73 \%$ & $1.61 \%$ \\
\hline Yuma, AZ & $-4.23 \%$ & $3.21 \%$ & $2.78 \%$ & $-0.77 \%$ & $1.44 \%$ & $5.42 \%$ & $2.56 \%$ & $3.62 \%$ & $-1.38 \%$ & $2.50 \%$ \\
\hline
\end{tabular}

Notes: The top immigration metropolitan areas included in Table 5 are the 16 metro areas with the highest immigration rate 1990-2009 and the four largest Metro areas with share of foreign-born above 30\%. 
Table 8

Summary of Poverty Effects of immigrants and actual poverty rate changes, for some relevant groups: National 1990-2000, 2000-2009

\begin{tabular}{lcccccccc}
\hline & \multicolumn{3}{c}{$\mathbf{1 9 9 0 - 2 0 0 0}$} & \multicolumn{3}{c}{$\mathbf{2 0 0 0 - 2 0 0 9}$} \\
\hline Skill Group & $\begin{array}{c}\text { Imputed to } \\
\text { immigration } \\
\begin{array}{c}\text { High } \\
\text { Estimates }\end{array}\end{array}$ & $\begin{array}{c}\text { Imputed to } \\
\text { Immigration } \\
\text { Preferred } \\
\text { estimates }\end{array}$ & $\begin{array}{c}\text { Imputed to } \\
\text { Immigration } \\
\text { Low } \\
\text { Estimates }\end{array}$ & Actual & $\begin{array}{c}\text { Imputed to } \\
\text { immigration, } \\
\text { High } \\
\text { Estimates }\end{array}$ & $\begin{array}{c}\text { Imputed to } \\
\text { Immigration, } \\
\text { Preferred } \\
\text { estimates }\end{array}$ & $\begin{array}{c}\text { Imputed to } \\
\text { Immigration, } \\
\text { Low } \\
\text { Estimates }\end{array}$ & Actual \\
\hline Overall, U.S.-Born & $0.02 \%$ & $-0.02 \%$ & $-0.04 \%$ & $-0.38 \%$ & $-0.07 \%$ & $-0.10 \%$ & $-0.12 \%$ & $2.10 \%$ \\
Male & $0.02 \%$ & $-0.02 \%$ & $-0.04 \%$ & $-0.09 \%$ & $-0.08 \%$ & $-0.08 \%$ & $-0.09 \%$ & $2.04 \%$ \\
Female & $0.02 \%$ & $-0.02 \%$ & $-0.04 \%$ & $-0.65 \%$ & $-0.06 \%$ & $-0.11 \%$ & $-0.13 \%$ & $2.18 \%$ \\
\hline Overall Black & $0.04 \%$ & $-0.01 \%$ & $-0.06 \%$ & $-2.90 \%$ & $-0.13 \%$ & $-0.17 \%$ & $-0.20 \%$ & $1.52 \%$ \\
Male & $0.04 \%$ & $-0.01 \%$ & $-0.05 \%$ & $-1.39 \%$ & $-0.09 \%$ & $-0.12 \%$ & $-0.14 \%$ & $1.98 \%$ \\
Female & $0.04 \%$ & $-0.01 \%$ & $-0.07 \%$ & $-4.15 \%$ & $-0.15 \%$ & $-0.20 \%$ & $-0.24 \%$ & $1.23 \%$ \\
\hline Overall Hispanic & $0.06 \%$ & $0.00 \%$ & $-0.06 \%$ & $-2.35 \%$ & $-0.15 \%$ & $-0.18 \%$ & $-0.21 \%$ & $-0.34 \%$ \\
Male & $0.05 \%$ & $-0.01 \%$ & $-0.06 \%$ & $-1.57 \%$ & $-0.15 \%$ & $-0.16 \%$ & $-0.18 \%$ & $-0.35 \%$ \\
Female & $0.07 \%$ & $0.00 \%$ & $-0.07 \%$ & $-3.11 \%$ & $-0.14 \%$ & $-0.20 \%$ & $-0.24 \%$ & $-0.16 \%$ \\
\hline
\end{tabular}

Note: The calculations are based on the imputed wage effects of immigrants, calculated based on the model in the text. The effect of immigration is calculated as the difference in poverty rates considering wage income with and without net immigration of the considered decade. 


\section{Figures}

Figure 1: Immigration and Poverty rates

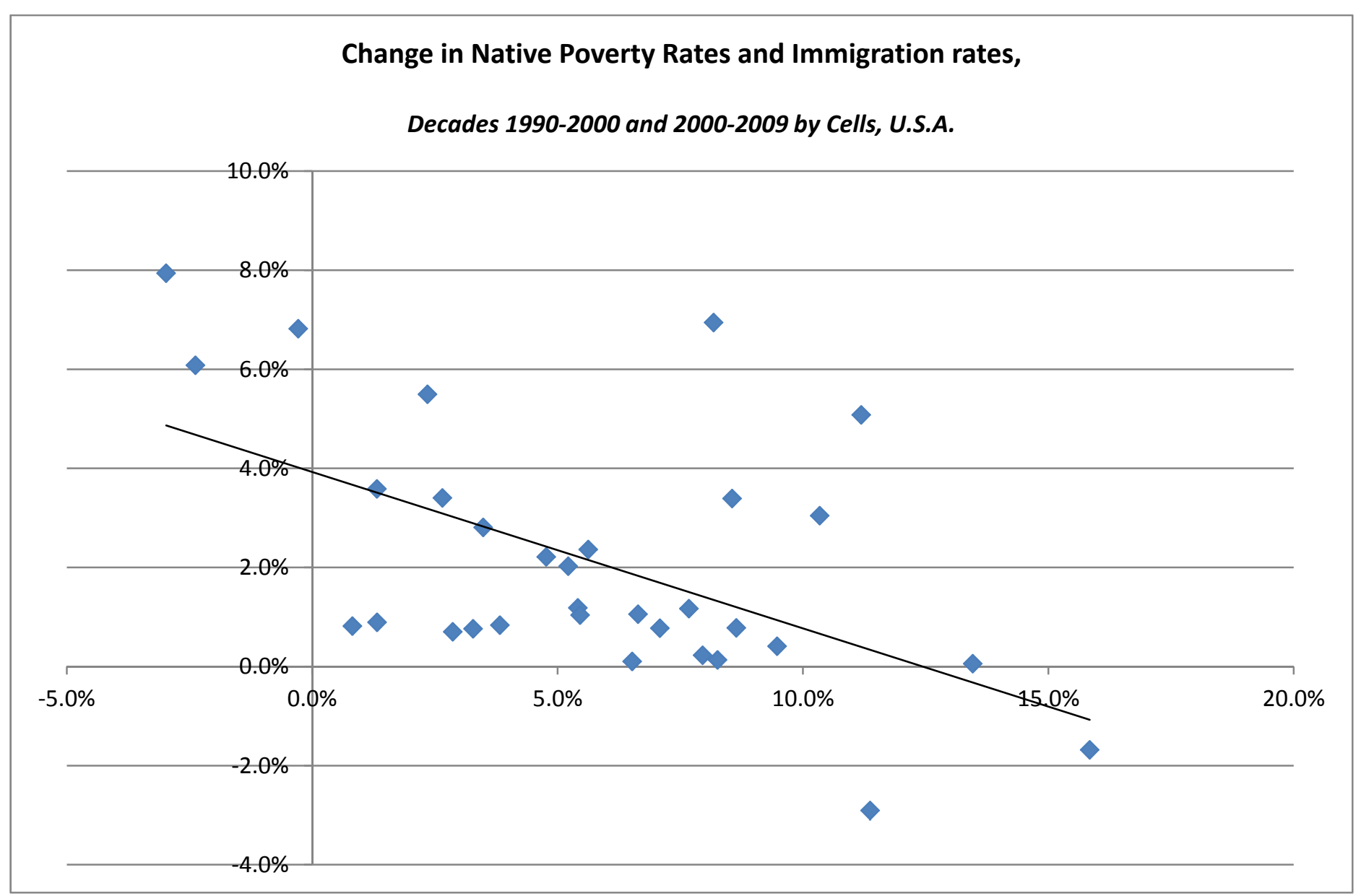

Note: The cells are Schooling by Experience by Gender groups as reported in Table 2 and 3. 
Figure 2: Immigration and Poverty rates across states

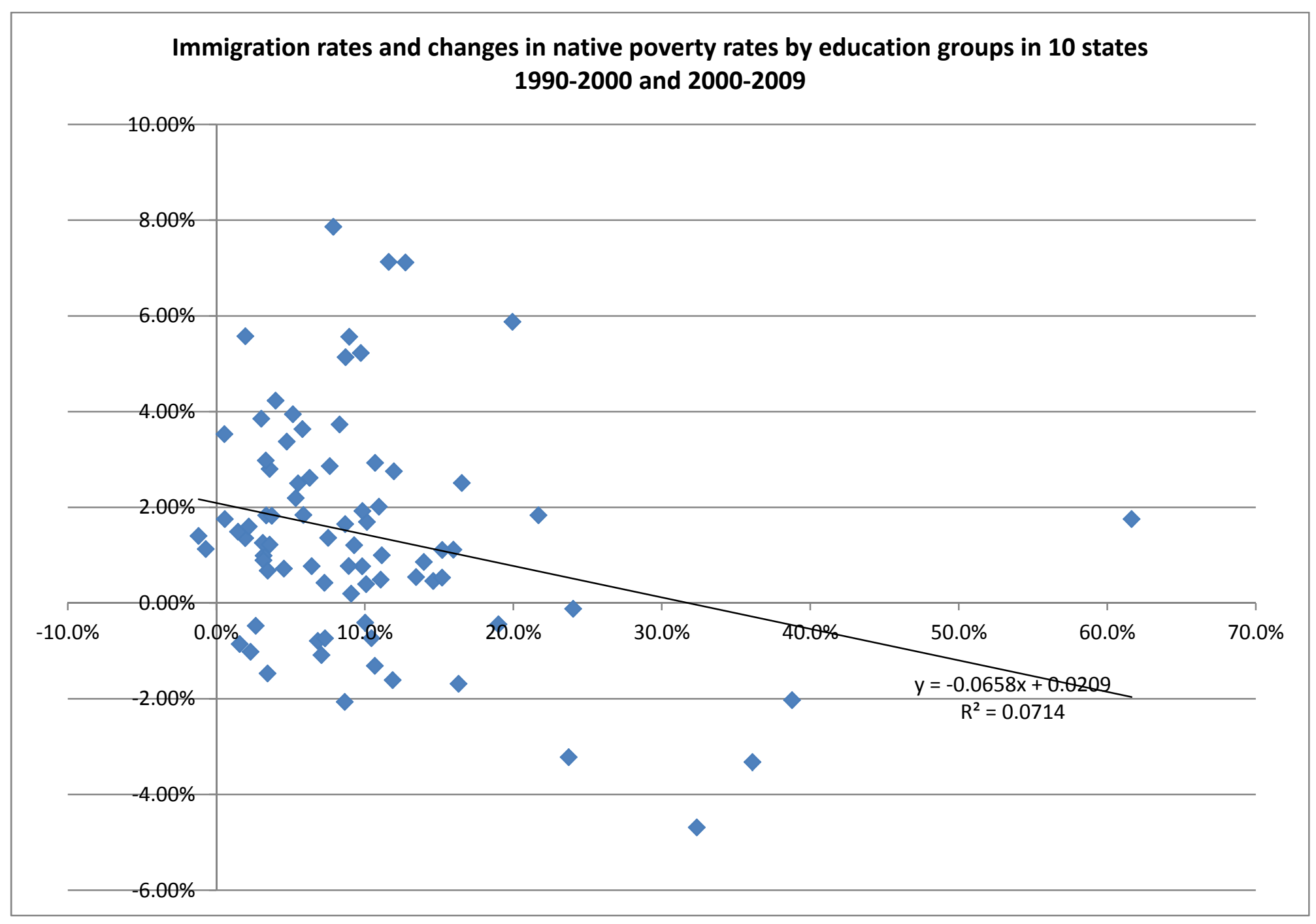




\section{Figure 3}

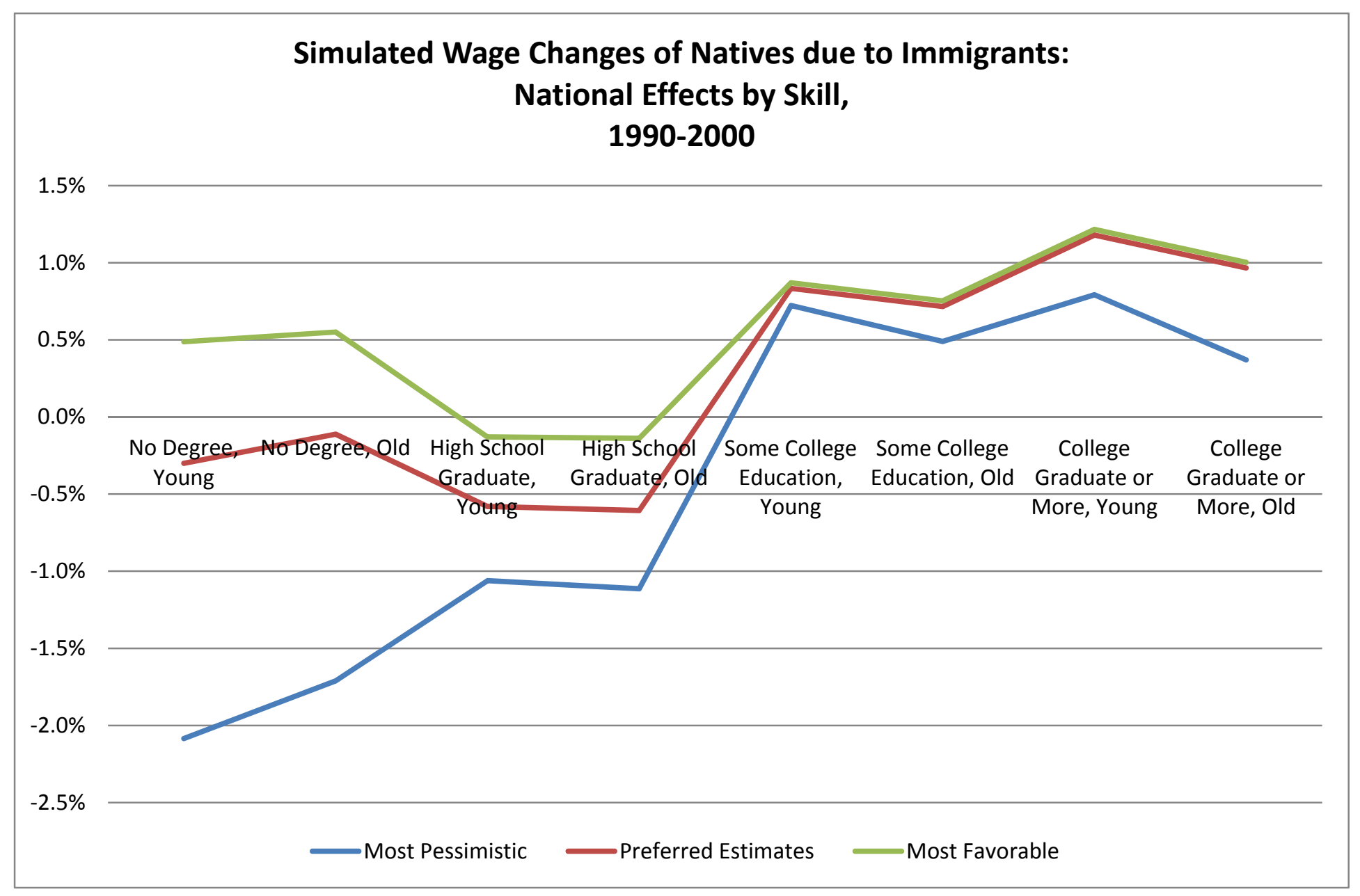

Note: the changes as percentage of the native wage are calculated using the model in the paper, and three parameter combinations, as described in the Table 1. The schooling groups are individuals with No Degree, High school Graduates, individuals with some college education and College graduates. Each schooling group is divided into Young (individuals with less than 20 years of potential labor market experience) and Old (Individuals with more than 20 years of potential labor market experience). We assumed that the national market is integrated in the long-run. 


\section{Figure 4}

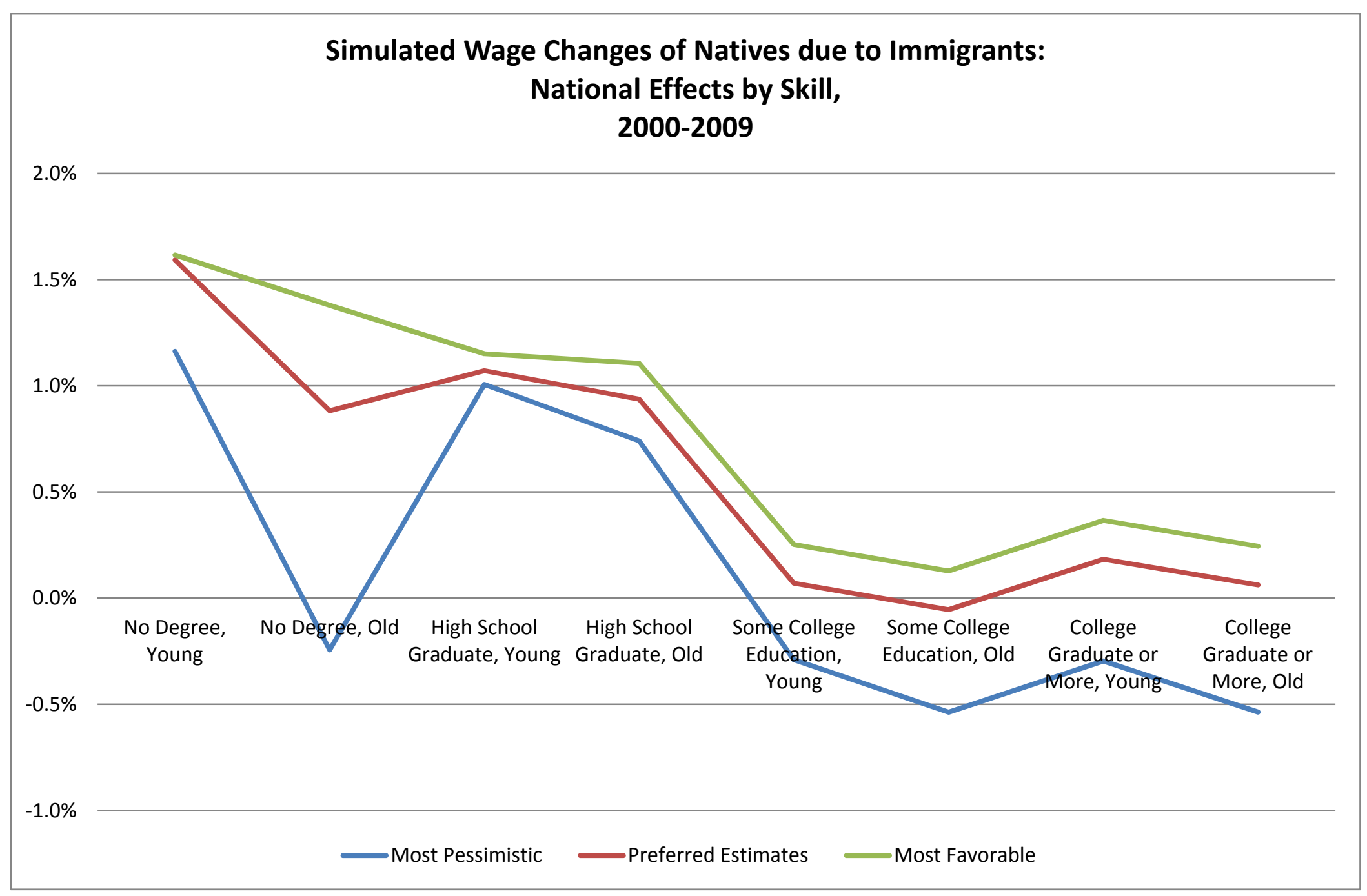

Note: the changes as percentage of the native wage are calculated using the model in the paper, and three parameter combinations, as described in the Table 1. The schooling groups are individuals with No Degree, High school Graduates, individuals with some college education and College graduates. Each schooling group is divided into Young (individuals with less than 20 years of potential labor market experience) and Old (Individuals with more than 20 years of potential labor market experience). We assumed that the national market is integrated in the long-run. 
Figure 5

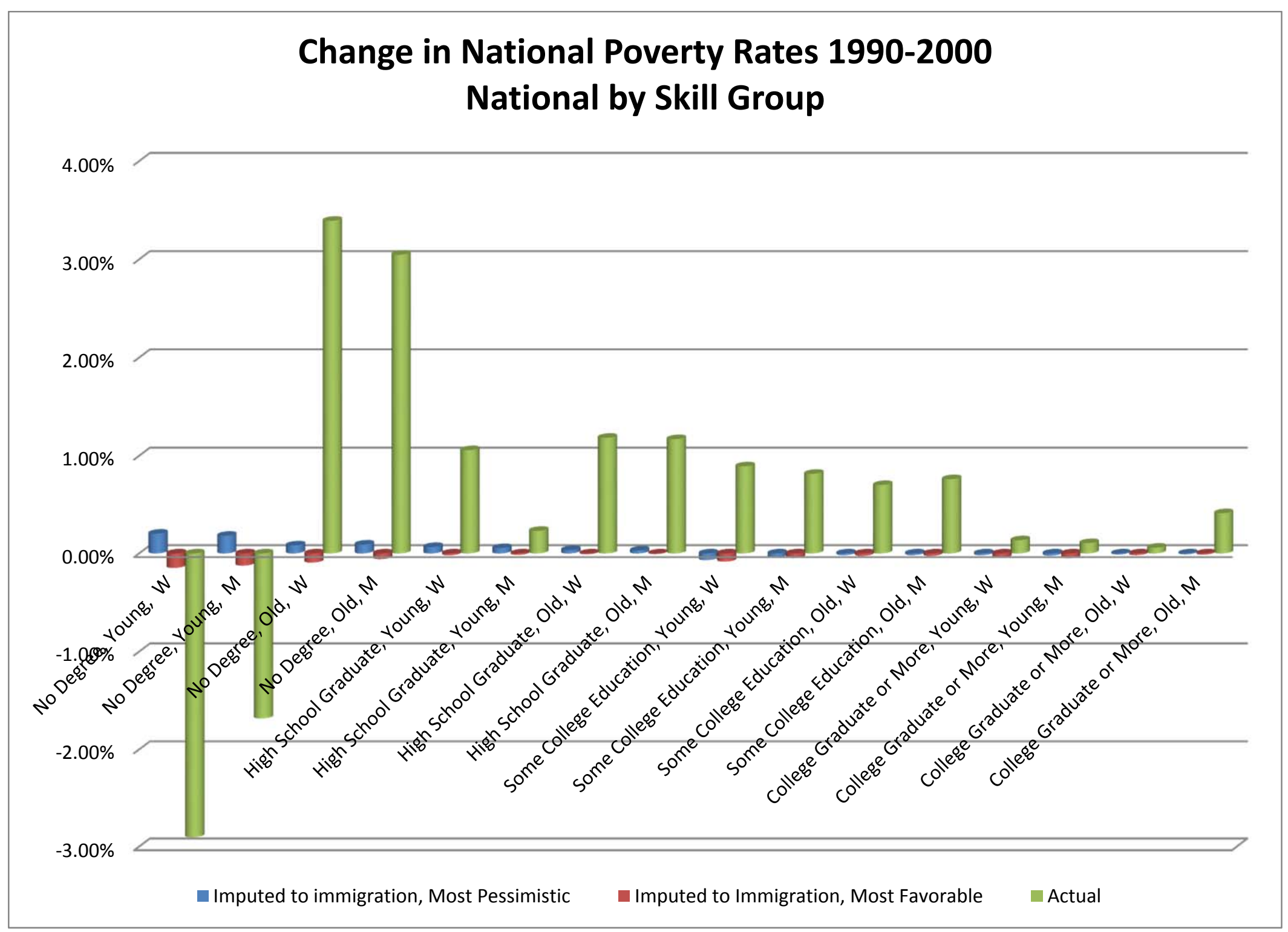


Figure 6

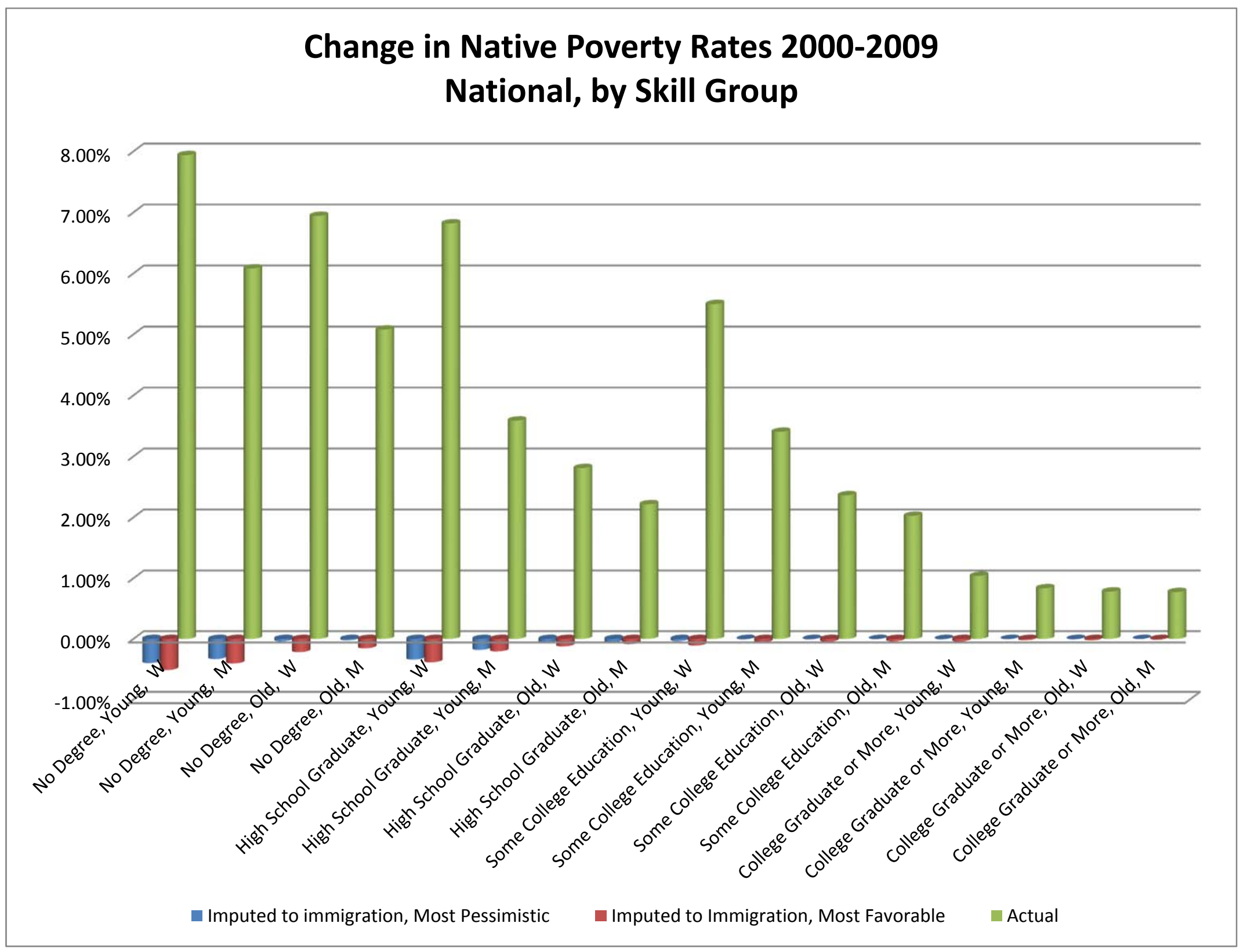




\section{Panel 7}

Effects of immigrants on native wages, by skill, assuming segmented state Labor Markets 2000-2009
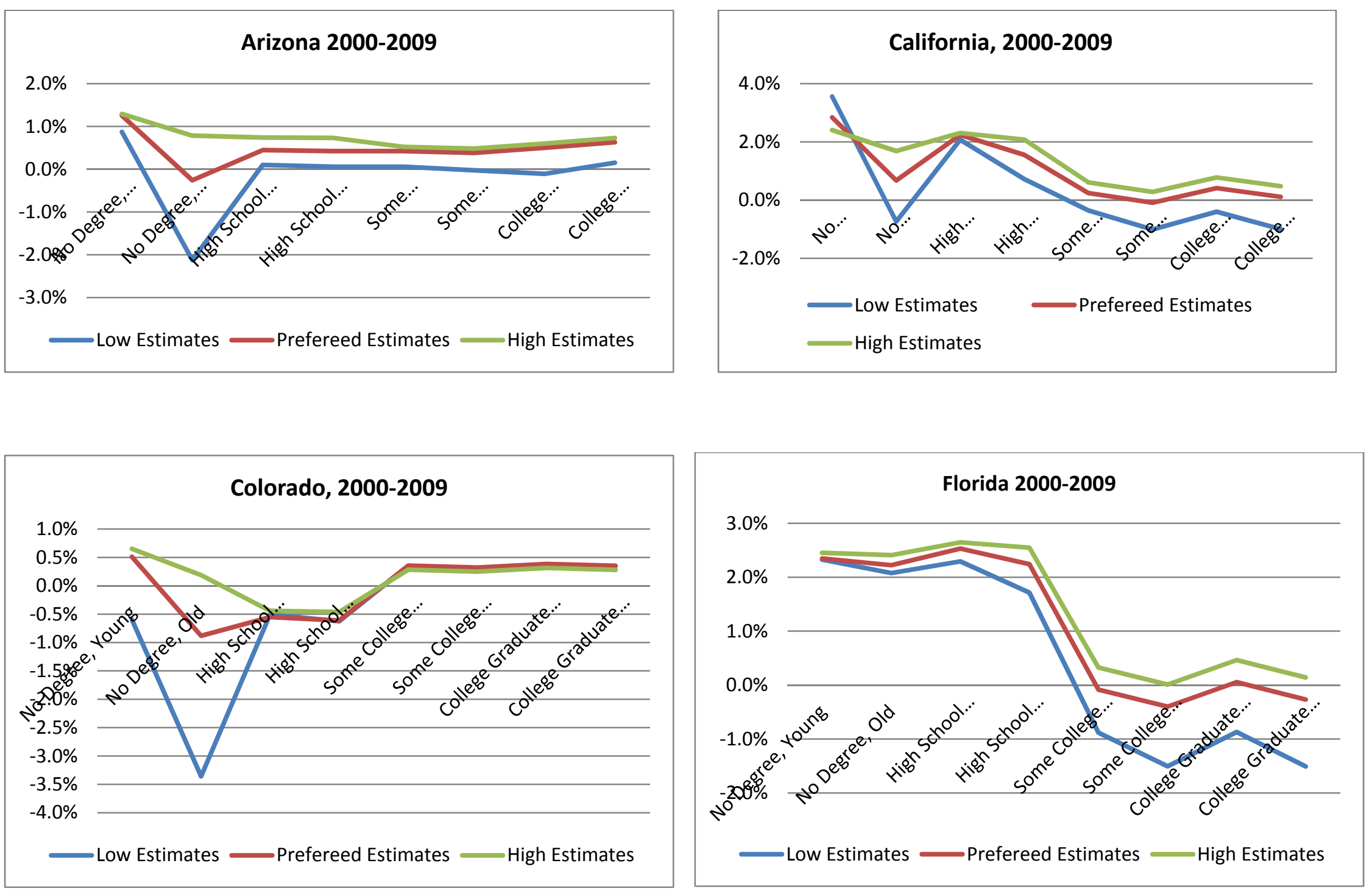


\section{Panel 7 (continued)}
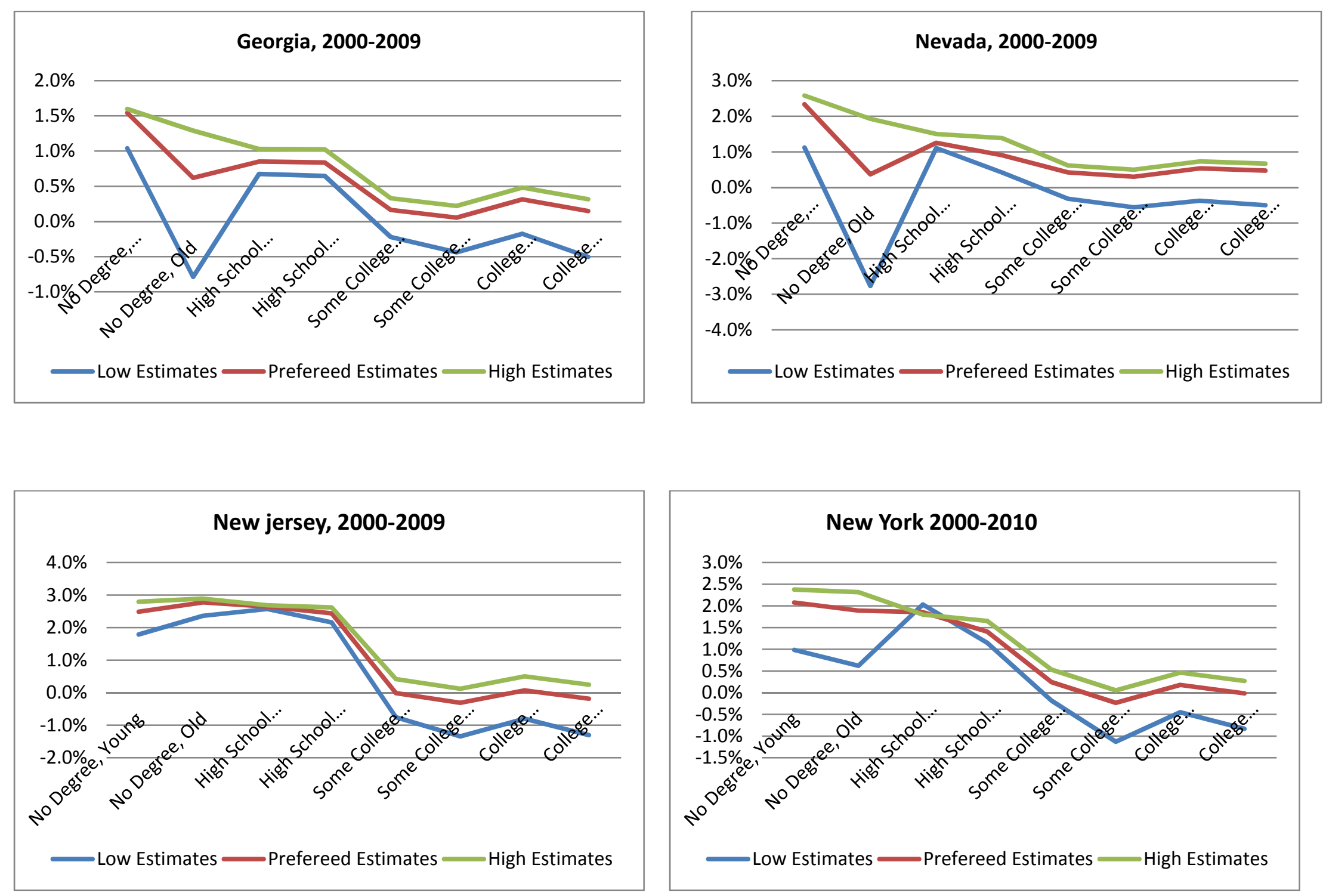


\section{Panel 7 (continued)}

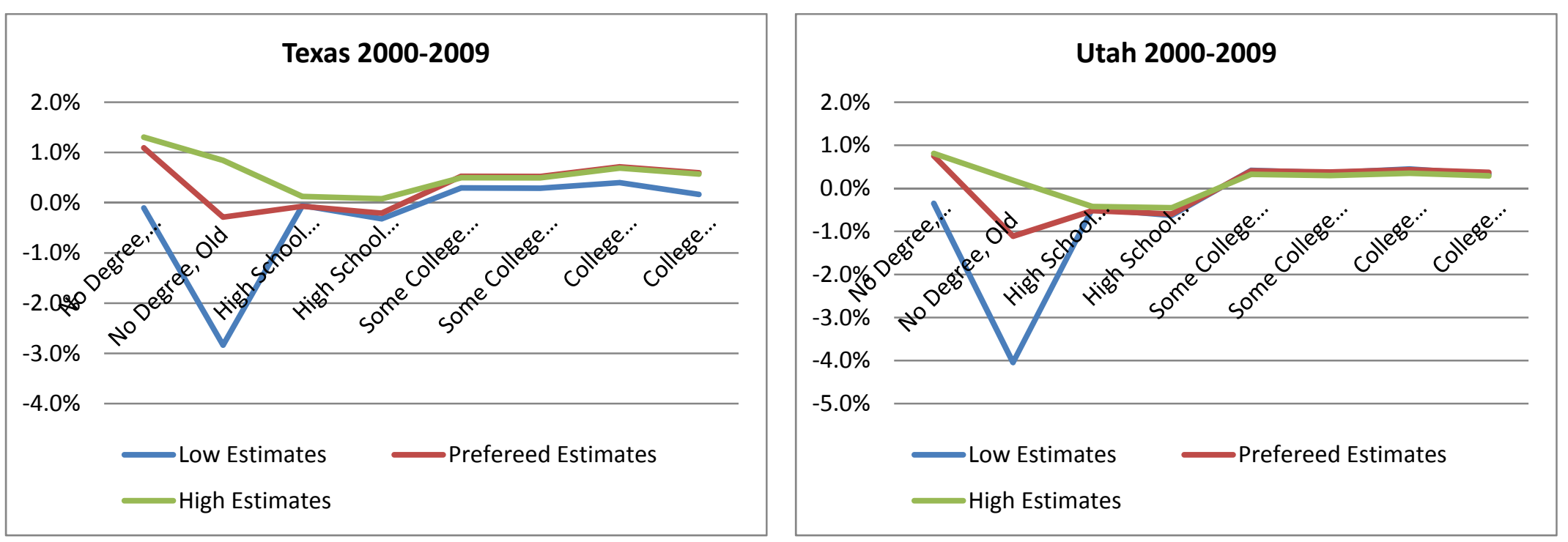


Figure 8

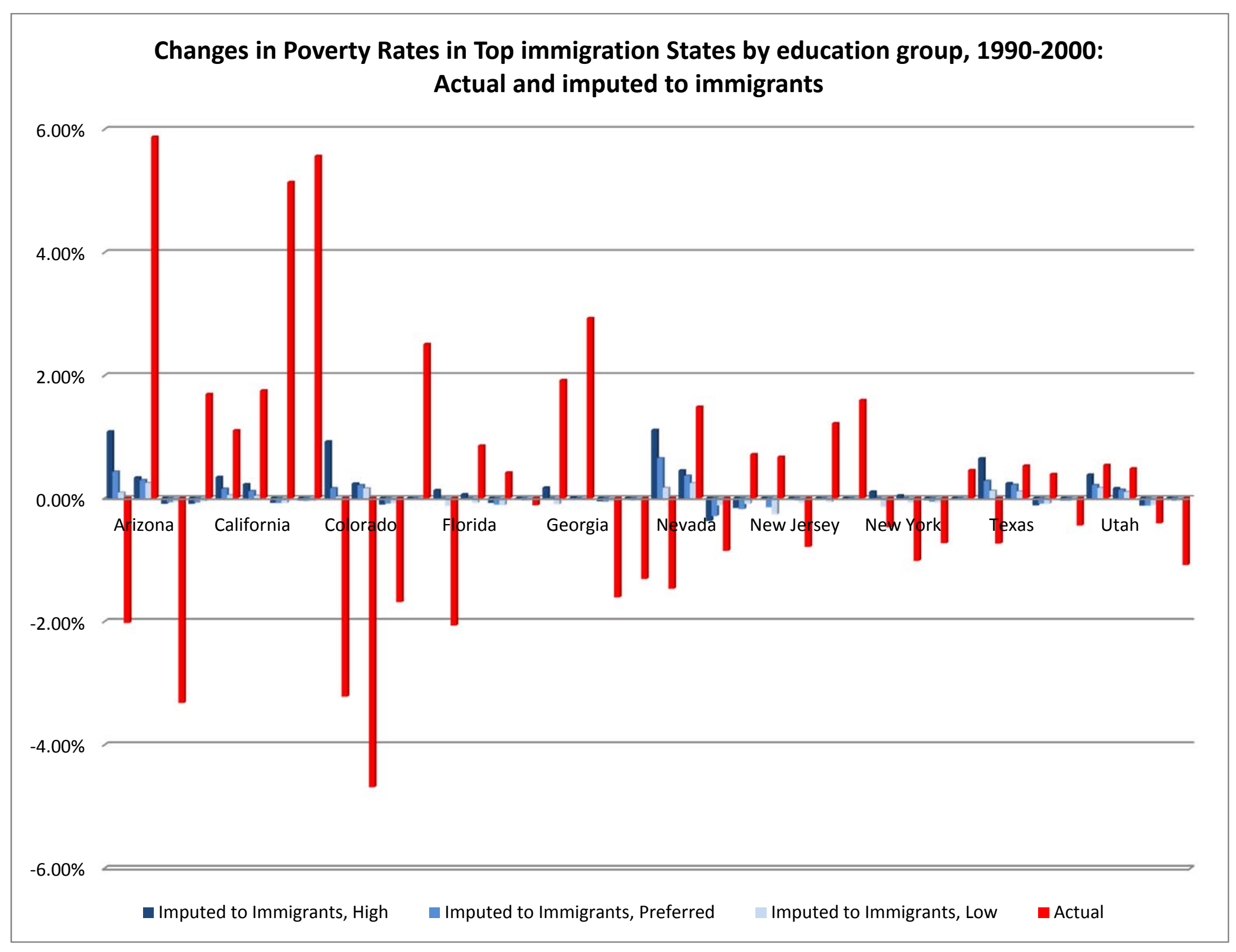


Figure 9

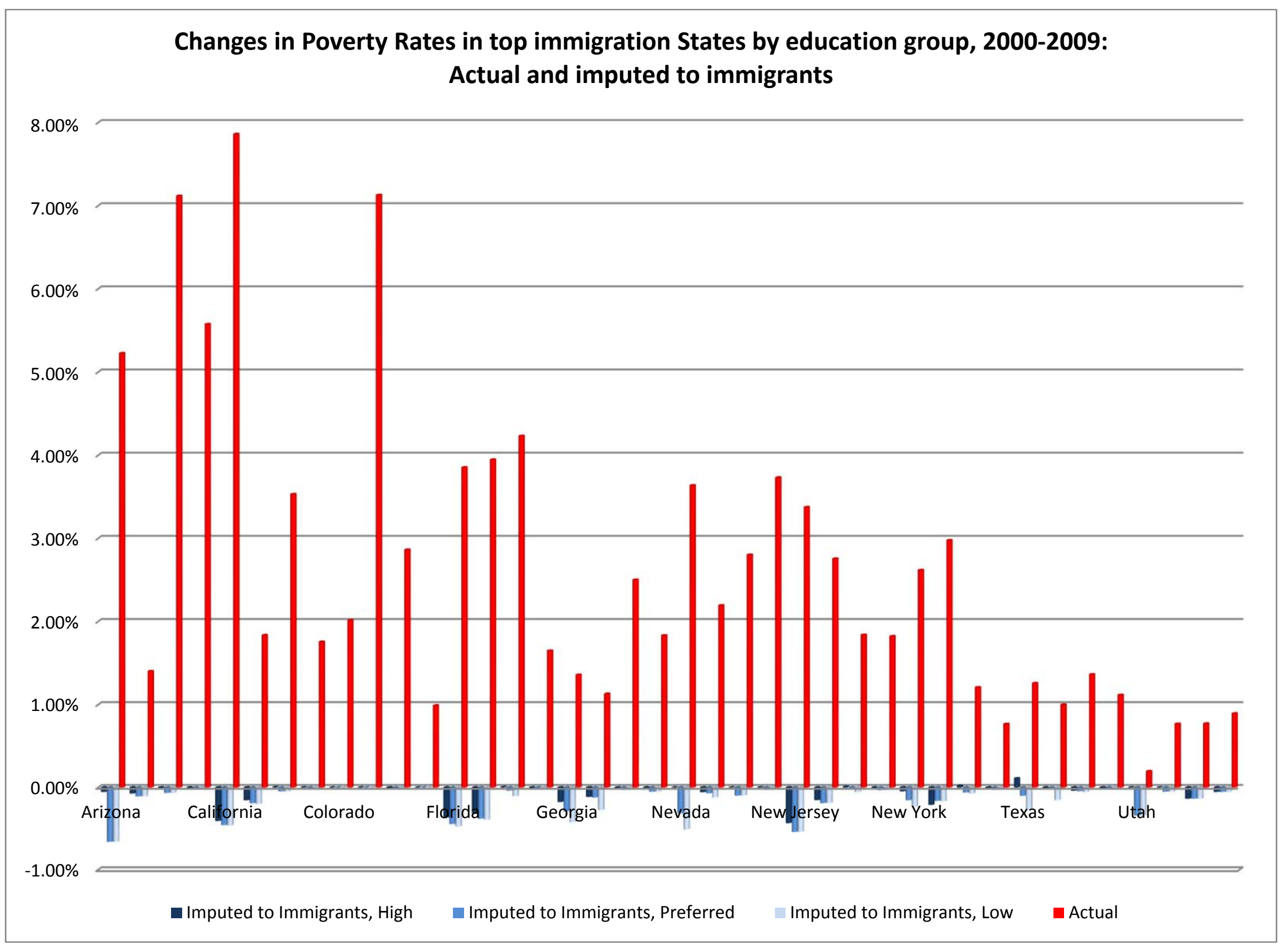




\section{Figure 10}

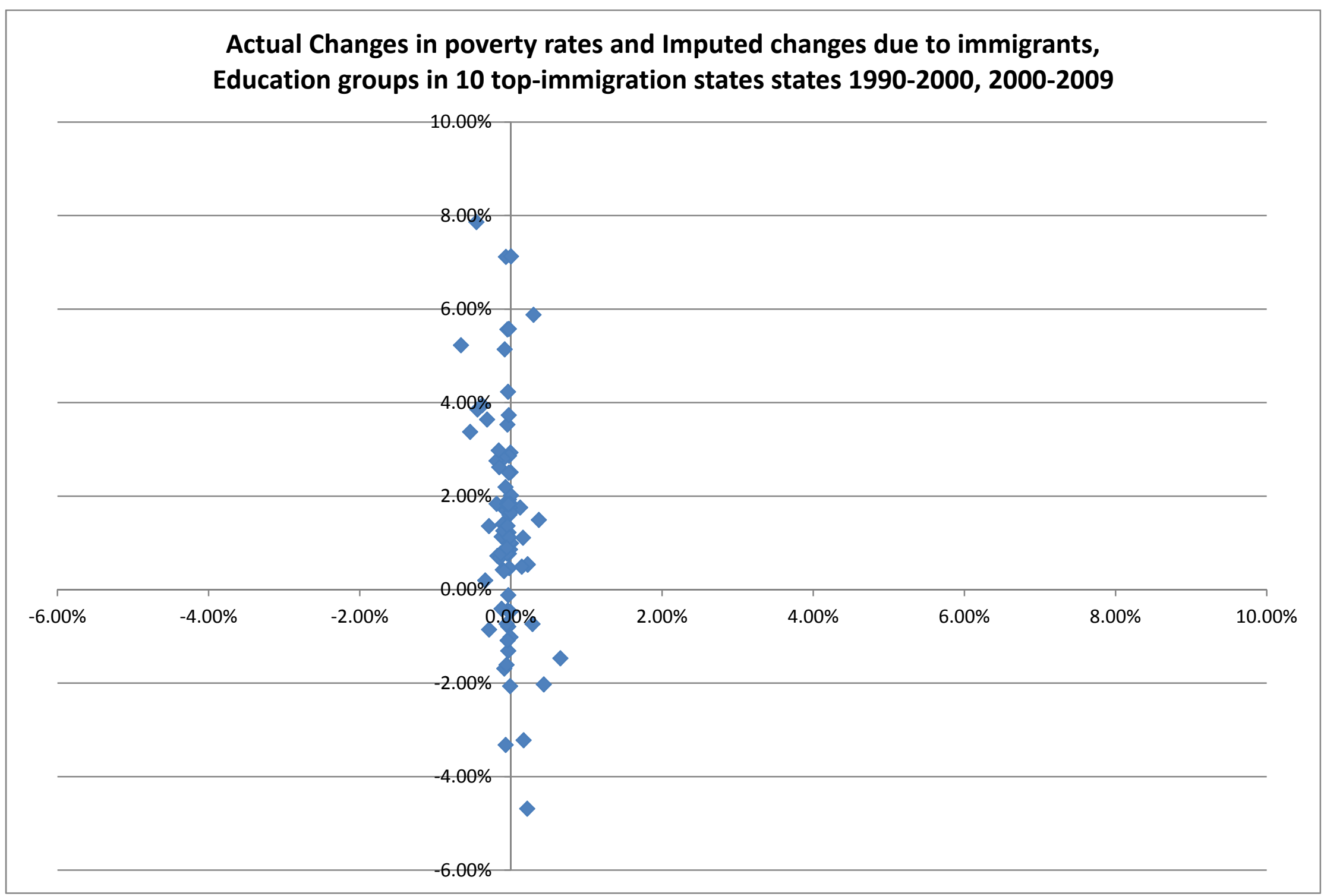

Note: The imputed changes use the preferred scenario simulations. Each cell is an education group in one of the 10 top immigration states over the decade 1990-2000 and 2000-2009. 
Figure 11: Wage Effects of Immigration by MSA, preferred estimates 2000-2009

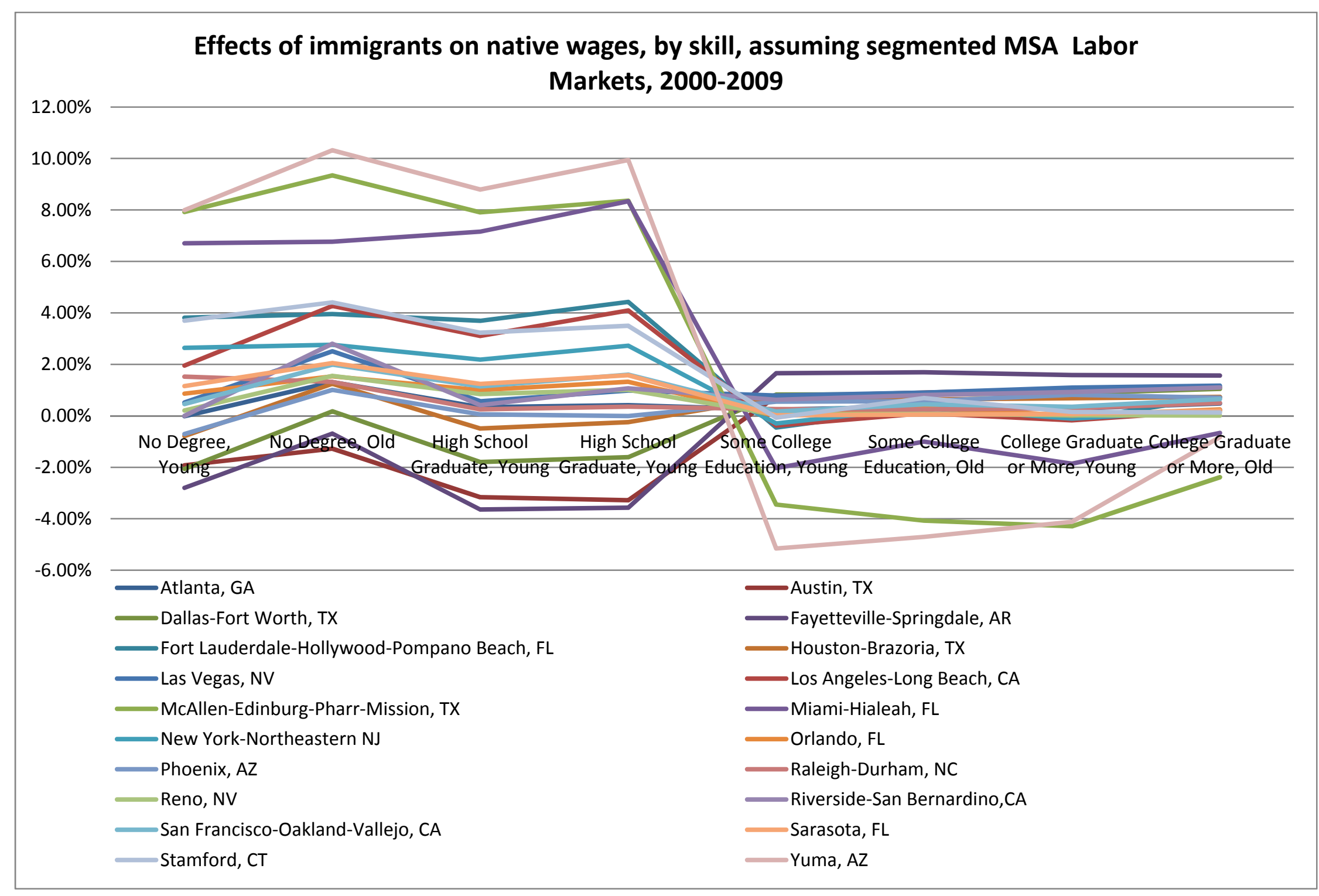


Figure 12: MSAs 1990-2000

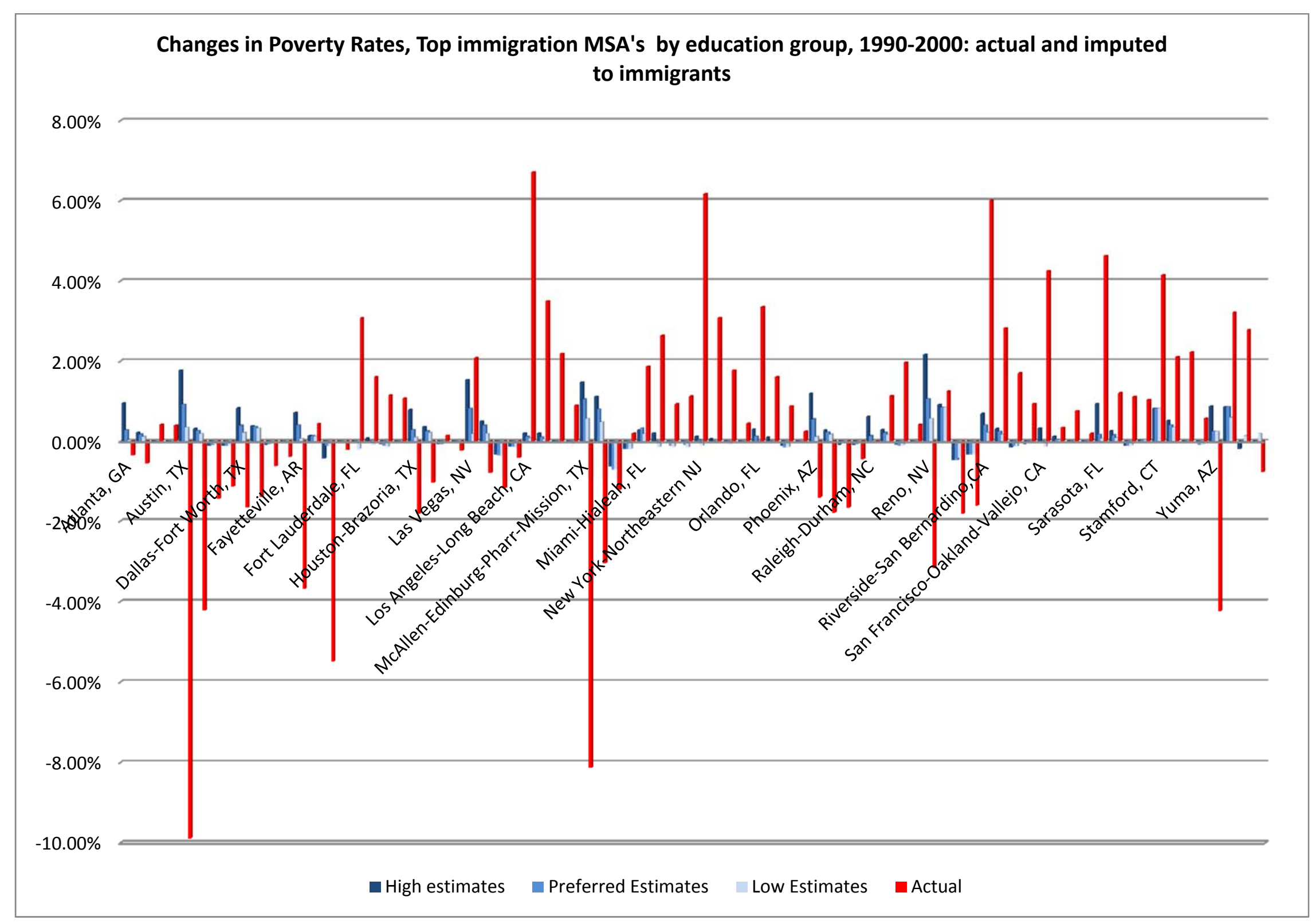


Table 13: MSAs 2000-2009

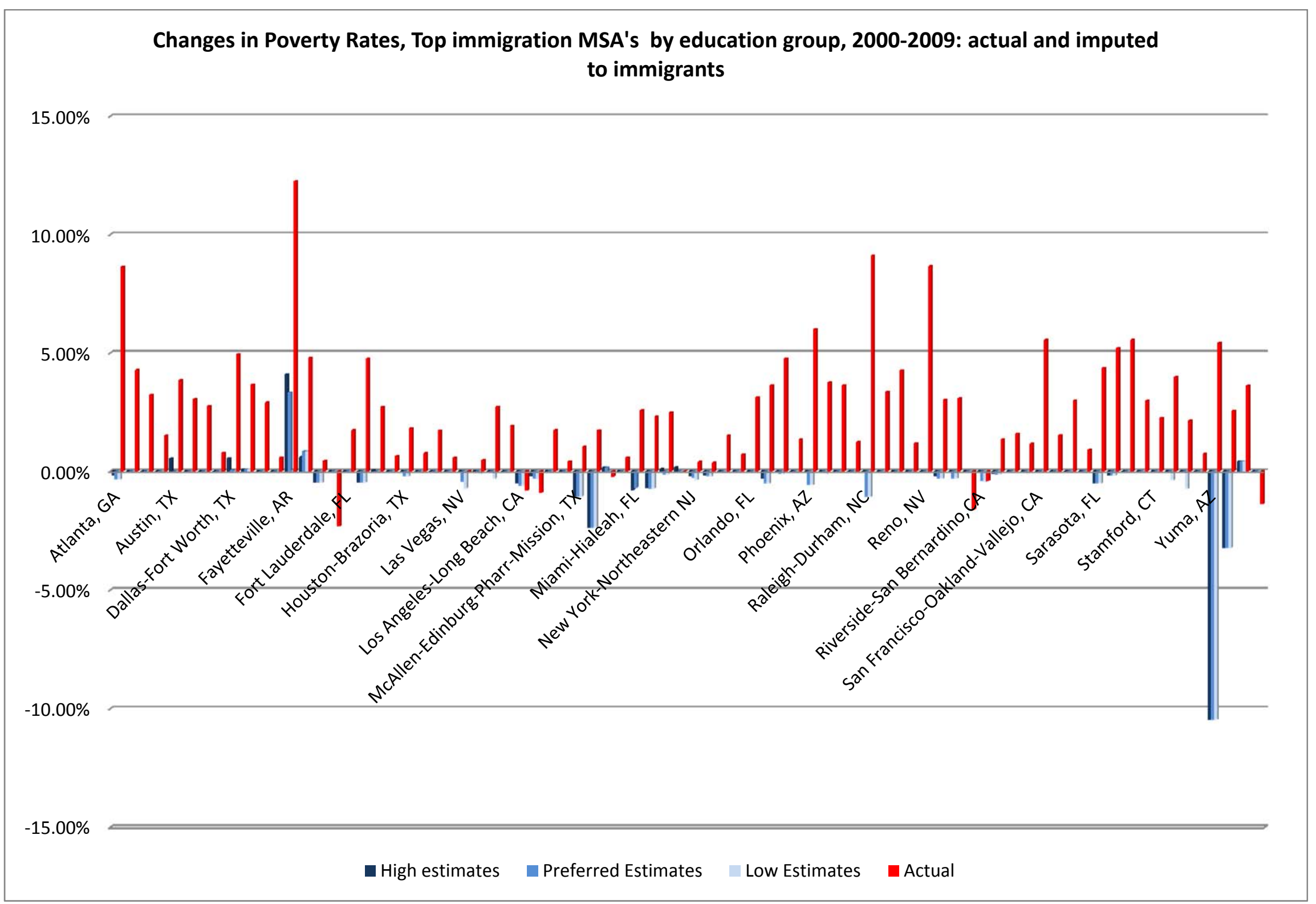




\section{Figure 14}

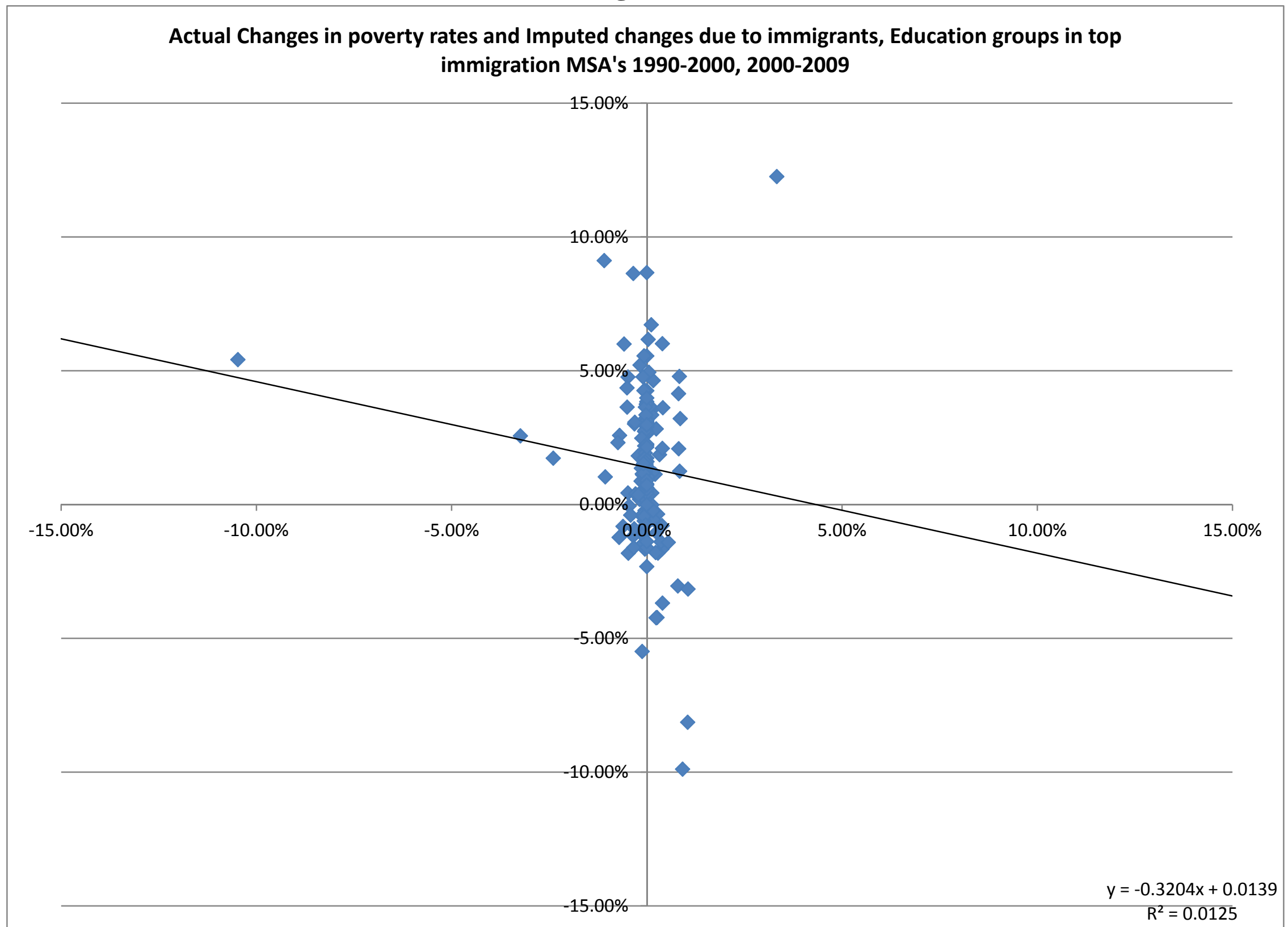


Tables and Figures Appendix

\section{Table A1:}

Federal Poverty Line for pre-transfer family income 2000 and 2009

Poverty Thresholds (yearly income) by Size of Family and Number of Children under 18 Years, In 2000 dollars. To obtain those in 2009 multiply by 0.773

\begin{tabular}{|c|c|c|c|c|c|c|c|c|c|}
\hline \multirow[t]{2}{*}{ Number of people } & \multicolumn{9}{|c|}{ Number of related children } \\
\hline & None & One & Two & Three & Four & Five & Six & Seven & Eight plus \\
\hline One person under 65 years & $\$ 8,667$ & & & & & & & & \\
\hline One person, 65 years or older & 7,990 & & & & & & & & \\
\hline Two people, RP under 65 years & 11,156 & $\$ 11,483$ & & & & & & & \\
\hline Two people, RP 65 years or older & 10,070 & 11,440 & & & & & & & \\
\hline Three people & 13,032 & 13,410 & $\$ 13,423$ & & & & & & \\
\hline Four people & 17,184 & 17,465 & 16,895 & $\$ 16,954$ & & & & & \\
\hline Five people & 20,723 & 21,024 & 20,380 & 19,882 & $\$ 19,578$ & & & & \\
\hline Six people & 23,835 & 23,930 & 23,436 & 22,964 & 22,261 & $\$ 21,845$ & & & \\
\hline Seven people & 27,425 & 27,596 & 27,006 & 26,595 & 25,828 & 24,934 & $\$ 23,953$ & & \\
\hline Eight people & 30,673 & 30,944 & 30,387 & 29,899 & 29,206 & 28,327 & 27,412 & $\$ 27,180$ & \\
\hline Nine or more people & 36,897 & 37,076 & 36,583 & 36,169 & 35,489 & 34,554 & 33,708 & 33,499 & $\$ 32,208$ \\
\hline
\end{tabular}

Source: U.S. Census Bureau, Demographic Surveys Division, Continuous Measurement Office. The poverty thresholds are the same for all parts of the country; they are not adjusted for regional, state, or local variations in the cost of living. For a detailed discussion of the poverty definition, see U.S. Census Bureau, Current Population Reports, Series P-60, No. 210, Poverty in the United States: 1999. 
Table A2

Simulated Wage Effects of Immigrants on Natives, US Market

\begin{tabular}{|c|c|c|c|c|c|c|}
\hline Period & $1990-2000$ & & & $2000-200$ & & \\
\hline Skill Group: & Low Estimates & $\begin{array}{l}\text { Preferred } \\
\text { Estimates }\end{array}$ & $\begin{array}{l}\text { High } \\
\text { Estimates }\end{array}$ & $\begin{array}{l}\text { Low } \\
\text { Estimates }\end{array}$ & $\begin{array}{l}\text { Preferred } \\
\text { Estimates }\end{array}$ & $\begin{array}{l}\text { High } \\
\text { Estimates }\end{array}$ \\
\hline No Degree, Young & $-2.1 \%$ & $-0.3 \%$ & $0.5 \%$ & $1.2 \%$ & $1.6 \%$ & $1.6 \%$ \\
\hline No Degree, Old & $-1.7 \%$ & $-0.1 \%$ & $0.6 \%$ & $-0.2 \%$ & $0.9 \%$ & $1.4 \%$ \\
\hline High School Graduate, Young & $-1.1 \%$ & $-0.6 \%$ & $-0.1 \%$ & $1.0 \%$ & $1.1 \%$ & $1.2 \%$ \\
\hline High School Graduate, Old & $-1.1 \%$ & $-0.6 \%$ & $-0.1 \%$ & $0.7 \%$ & $0.9 \%$ & $1.1 \%$ \\
\hline Some College Education, Young & $0.7 \%$ & $0.8 \%$ & $0.9 \%$ & $-0.3 \%$ & $0.1 \%$ & $0.3 \%$ \\
\hline Some College Education, Old & $0.5 \%$ & $0.7 \%$ & $0.8 \%$ & $-0.5 \%$ & $-0.1 \%$ & $0.1 \%$ \\
\hline College Graduate or More, Young & $0.8 \%$ & $1.2 \%$ & $1.2 \%$ & $-0.3 \%$ & $0.2 \%$ & $0.4 \%$ \\
\hline College Graduate or More, Old & $0.4 \%$ & $1.0 \%$ & $1.0 \%$ & $-0.5 \%$ & $0.1 \%$ & $0.2 \%$ \\
\hline Total Effect, U.S.-Born & $0.0 \%$ & $0.5 \%$ & $0.7 \%$ & $0.0 \%$ & $0.4 \%$ & $0.6 \%$ \\
\hline
\end{tabular}

Note: the changes as percentage of the native wage are calculated using the model in the paper, and three parameter combinations, as described in the Table 1 . We assumed that the national market is integrated in the long-run. 
Table A3

Imputed effects of immigration on native poverty rates and actual changes in poverty rates, National 1990-2000 and 2000-2009

\begin{tabular}{|c|c|c|c|c|c|c|c|c|}
\hline \multirow[b]{2}{*}{ Skill Group } & \multicolumn{4}{|c|}{$1990-2000$} & \multicolumn{4}{|c|}{ 2000-2009 } \\
\hline & $\begin{array}{c}\text { Imputed to } \\
\text { immigration } \\
\text { High } \\
\text { Estimates } \\
\end{array}$ & $\begin{array}{c}\text { Imputed to } \\
\text { Immigration } \\
\text { Preferred } \\
\text { estimates } \\
\end{array}$ & $\begin{array}{c}\text { Imputed to } \\
\text { Immigration } \\
\text { Low } \\
\text { Estimates } \\
\end{array}$ & Actual & $\begin{array}{c}\text { Imputed to } \\
\text { immigration, } \\
\text { High } \\
\text { Estimates } \\
\end{array}$ & $\begin{array}{c}\text { Imputed to } \\
\text { Immigration, } \\
\text { Preferred } \\
\text { estimates } \\
\end{array}$ & $\begin{array}{c}\text { Imputed to } \\
\text { Immigration, } \\
\text { Low } \\
\text { Estimates } \\
\end{array}$ & Actual \\
\hline No Degree, Young, W & $0.20 \%$ & $-0.01 \%$ & $-0.15 \%$ & $-2.90 \%$ & $-0.40 \%$ & $-0.48 \%$ & $-0.51 \%$ & $7.94 \%$ \\
\hline No Degree, Young, M & $0.18 \%$ & $-0.01 \%$ & $-0.12 \%$ & $-1.68 \%$ & $-0.33 \%$ & $-0.37 \%$ & $-0.40 \%$ & $6.08 \%$ \\
\hline No Degree, Old, W & $0.08 \%$ & $-0.01 \%$ & $-0.09 \%$ & $3.39 \%$ & $-0.04 \%$ & $-0.13 \%$ & $-0.22 \%$ & $6.94 \%$ \\
\hline No Degree, Old, $\mathrm{M}$ & $0.09 \%$ & $0.00 \%$ & $-0.06 \%$ & $3.05 \%$ & $-0.02 \%$ & $-0.09 \%$ & $-0.15 \%$ & $5.08 \%$ \\
\hline High School Graduate, Young, W & $0.07 \%$ & $-0.01 \%$ & $-0.02 \%$ & $1.06 \%$ & $-0.34 \%$ & $-0.36 \%$ & $-0.38 \%$ & $6.82 \%$ \\
\hline High School Graduate, Young, M & $0.05 \%$ & $0.00 \%$ & $-0.01 \%$ & $0.23 \%$ & $-0.18 \%$ & $-0.20 \%$ & $-0.21 \%$ & $3.59 \%$ \\
\hline High School Graduate, Old, W & $0.03 \%$ & $0.00 \%$ & $-0.01 \%$ & $1.18 \%$ & $-0.06 \%$ & $-0.07 \%$ & $-0.12 \%$ & $2.81 \%$ \\
\hline High School Graduate, Old, M & $0.03 \%$ & $0.00 \%$ & $-0.01 \%$ & $1.17 \%$ & $-0.05 \%$ & $-0.06 \%$ & $-0.08 \%$ & $2.22 \%$ \\
\hline Some College Education, Young, W & $-0.07 \%$ & $-0.08 \%$ & $-0.08 \%$ & $0.89 \%$ & $-0.04 \%$ & $-0.11 \%$ & $-0.11 \%$ & $5.50 \%$ \\
\hline Some College Education, Young, M & $-0.04 \%$ & $-0.05 \%$ & $-0.05 \%$ & $0.82 \%$ & $-0.01 \%$ & $-0.06 \%$ & $-0.06 \%$ & $3.40 \%$ \\
\hline Some College Education, Old, W & $-0.02 \%$ & $-0.02 \%$ & $-0.03 \%$ & $0.70 \%$ & $-0.01 \%$ & $-0.01 \%$ & $-0.05 \%$ & $2.36 \%$ \\
\hline Some College Education, Old, M & $-0.02 \%$ & $-0.02 \%$ & $-0.02 \%$ & $0.76 \%$ & $0.00 \%$ & $0.00 \%$ & $-0.04 \%$ & $2.03 \%$ \\
\hline College Graduate or More, Young, W & $-0.02 \%$ & $-0.04 \%$ & $-0.04 \%$ & $0.13 \%$ & $-0.01 \%$ & $-0.04 \%$ & $-0.04 \%$ & $1.04 \%$ \\
\hline College Graduate or More, Young, M & $-0.02 \%$ & $-0.05 \%$ & $-0.05 \%$ & $0.11 \%$ & $0.00 \%$ & $-0.02 \%$ & $-0.02 \%$ & $0.84 \%$ \\
\hline College Graduate or More, Old, W & $-0.01 \%$ & $-0.01 \%$ & $-0.02 \%$ & $0.06 \%$ & $-0.01 \%$ & $-0.02 \%$ & $-0.02 \%$ & $0.78 \%$ \\
\hline College Graduate or More, Old, M & $-0.01 \%$ & $-0.01 \%$ & $-0.01 \%$ & $0.41 \%$ & $0.00 \%$ & $-0.01 \%$ & $-0.01 \%$ & $0.77 \%$ \\
\hline Overall, U.S.-Born & $0.02 \%$ & $-0.02 \%$ & $-0.04 \%$ & $2.10 \%$ & $-0.07 \%$ & $-0.10 \%$ & $-0.12 \%$ & $4.00 \%$ \\
\hline
\end{tabular}




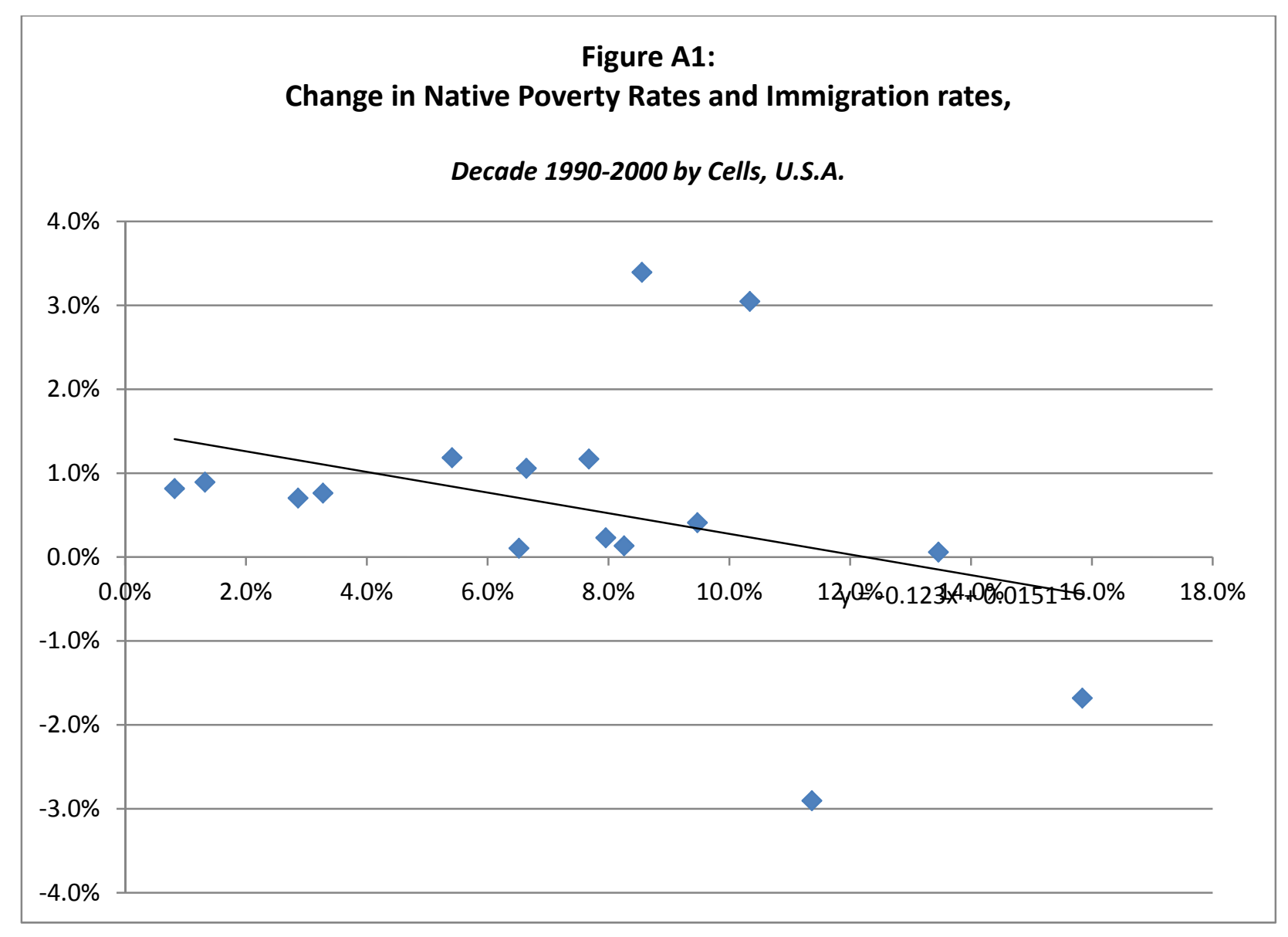

Note: Cells are groups by education, experience and gender as defined in Table 2 and 3 


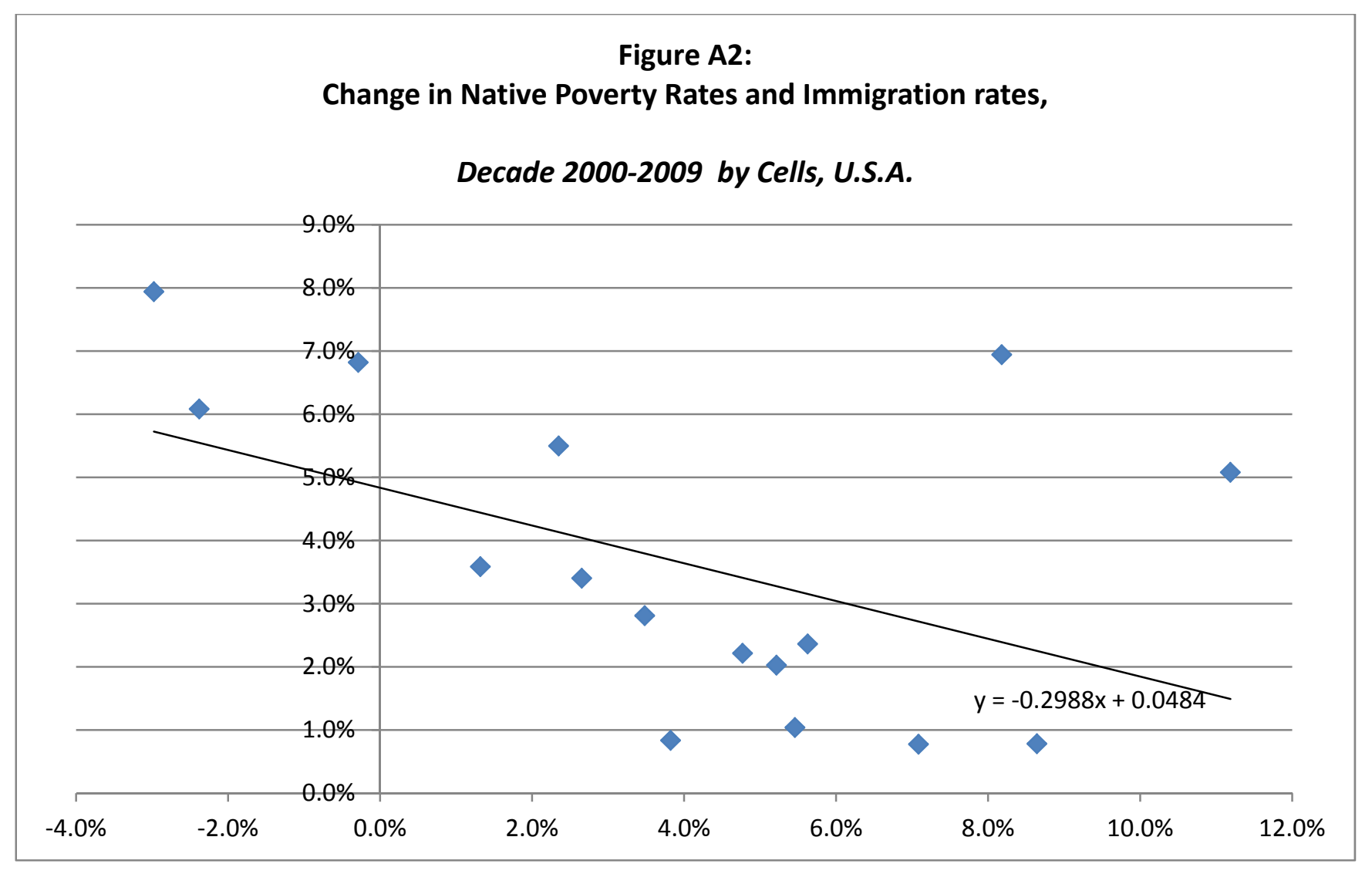

Note: Cells are groups by education, experience and gender as defined in Table 2 and 3 